\title{
THE PRACTICE AND LEGALITY OF RENDITION
}

by Katherine Hawkins

165 South St.

Needham, MA 02492

k_r_hawkins@yahoo.com

$617-285-0304$ 


\section{THE PRACTICE AND LEGALITY OF RENDITION}

In January 2004, a Canadian citizen named Maher Arar filed a lawsuit in a Brooklyn District Court ${ }^{1}$ against John Ashcroft, Tom Ridge, the directors of the FBI and INS, and other U.S. law enforcement officials. The complaint alleged the following:

U.S. immigration officials stopped and questioned Arar when he was changing flights at John F. Kennedy International Airport (“JFK airport”) on September 26, 2002. ${ }^{2}$ He was imprisoned in solitary confinement for thirteen days, first at a facility near the airport and then at the Brooklyn Metropolitan Detention Center, and interrogated about alleged ties to al-Qaeda. ${ }^{3}$ Arar was initially denied access to counsel, and then his attorney was given misleading information about his whereabouts. ${ }^{4}$ On October 8 immigration officials told him that he would be deported to Syria, despite his repeated protests that he was a Canadian citizen ${ }^{5}$ and would be tortured if he was sent to Damascus. ${ }^{6}$ Arar was driven in shackles to an airfield in New Jersey, and placed on a private jet. ${ }^{7}$ The plane flew first to Washington, D.C., and then to Amman, Jordan. ${ }^{8}$ The U.S. turned Arar over to Jordanian officials, who briefly interrogated and beat him and then transferred him to Syrian custody. ${ }^{9}$

Arar was taken to a Syrian military intelligence facility called the Palestine Branch. ${ }^{10}$ For the first twelve days of his imprisonment there, he was tortured and interrogated for eighteen hours a

${ }^{1}$ Plaintiff's Complaint, Arar v. Ashcroft, filed Jan. 22, 2004. (E.D.N.Y.) (No. CV-00249).

2 Id. at बाव $26-29$.

${ }^{3}$ Id. at $9932-36$.

${ }^{4}$ Id. at 9 ฯ $37,38,42,43,44,46$.

${ }^{5}$ Arar was born in Syria, and emigrated to Canada in 1987 at the age of 17. Bruce Cheadle, Mystery Goes Unsolved; Canadians Unlikely to Ever Learn Full Story of Syrian-Born Canadian Being Detained in Syria Prison: Expert, Hamilton Spectator, Oct. 7, 2003, at A14. Syria does not allow its citizens to renounce their citizenship, so Arar was technically a dual citizen of Canada and Syria.

6 Plaintiff's Complaint, Arar v. Ashcroft, at 94 35, 40, 44, 47.

${ }^{7} I d$. at 94.

8 Id. at 9 甲 $49-50$

${ }^{9}$ Id. at 950.

${ }^{10} \mathrm{Id}$. at 950. 
day. ${ }^{11}$ Security officers "regularly beat him on the palms, hips, and lower back, using a two-inch thick electrical cable. They also regularly struck Mr. Arar in the stomach, face, and back of the neck with their fists." 12 They placed Arar where he could hear the screams of other prisoners who were being tortured. ${ }^{13}$ They "threatened to place him in the spine-breaking 'chair,' hang him upside down in a 'tyre' and beat him, and give him electric shocks." 14 Arar noticed that the questions the Syrian officials asked him were very similar to those asked by the FBI agents in JFK airport. ${ }^{15}$ To stop them from torturing him, he confessed falsely to a number of charges, including traveling to Afghanistan for terrorism training. ${ }^{16}$

The beatings stopped after the Canadian Embassy made contact with Arar on October 20, 2002, but Arar spent most of the next ten months confined to an underground cell that was three feet wide, seven feet high, and six feet long. ${ }^{17}$ The cell was damp, cold, almost completely dark, and had no sanitary facilities. ${ }^{18}$ Arar was not permitted to exercise, was allowed to bathe once a week in cold water, and was not fed adequately. ${ }^{19} \mathrm{He}$ lost forty pounds during this period. ${ }^{20}$ In August of 2003, Syrian officials forced Arar to sign a false confession and transferred him to another prison for six weeks, before returning him to the Palestine Branch. ${ }^{21}$ On October 5, 2003, they told him he had been cleared of all charges and released him. ${ }^{22}$

The complaint charged that the defendants knew exactly what would happen to Arar in Syria, and sent him there for that reason:

\footnotetext{
11 Id. at 951.

$12 \mathrm{Id}$. at 91 .

13 Id. at 952.

14 Id. at 95.

15 Id. at 94.

16 Id. at 53 .

${ }^{17} \mathrm{Id}$. at $9 \uparrow 58,60$.

18 Id. at 99.

${ }^{19} \mathrm{Id}$. at 95.

${ }^{20} I d$. at 959.

${ }^{21} \mathrm{Id}$. at $9 \uparrow 62$ - 63.

22 Id. at 64.
} 
Defendants conspired with officials in the Syrian government and/or aided and abetted Syrian government officials in their plan to arbitrarily detain, interrogate, and torture Mr. Arar. Defendants intentionally detained Mr. Arar and then removed him to Syria so that Syrian authorities could interrogate him under torture. ${ }^{23}$

It also charged that the defendants continued to collaborate with Syrian intelligence during

Arar's imprisonment and torture:

On information and belief, Defendants provided their Syrian counterparts a dossier on Mr. Arar, compiled in part from the interrogations at JFK. On information and belief, Defendants suggested matters to be covered by Syrian security officers during Mr. Arar's interrogation.... On information and belief, Syrian security officers turned over to the Defendants all information coerced from Mr. Arar during his interrogations under torture in Syria. ${ }^{24}$

Arar is suing the government officials in both their official and private capacities, under the

U.S. Constitution, the Torture Victim Protection Act, and the Convention Against Torture and

Other Cruel, Inhuman or Degrading Treatment or Punishment (hereinafter "Convention Against

Torture", "CAT" or "Torture Convention") for a declaration that the defendants acted illegally as

well as compensatory and punitive damages. ${ }^{25}$

Maher Arar's lawsuit is the first direct legal challenge to the U.S. practice of sending terrorism suspects to be interrogated in countries that routinely torture prisoners. This policy, which the CIA calls "rendition" and human rights groups call "torture outsourcing," began in the mid1990s but has become more common and operated with fewer legal constraints since September 11. Human rights groups have estimated that there have been " 100 to 150 " 26 or " 150 to 200 " 27 renditions since the 2001 attacks. Rendition may become even more common if the U.S. government is dissatisfied with the restrictions that courts impose on the detention center at Guantánamo Bay.

The government and individual defendants have not yet filed an answer to Arar's factual allegations or his arguments about the legality of rendition. Instead they have moved to dismiss

23 Id. at 93.

24 Id. at $9 \uparrow 55-56$.

$25 I d$. at 9 ब 1 - 6

26 Douglas Jehl \& David Johnston, Rule Change Lets CIA Freely Send Suspects Abroad to Jails, N.Y. TimES, Mar. 6, 2005.

27 Michael Gawenda, U.S. Defends "Rendition” of Terror Suspects, THE AGE (Australia), Mar. 9, 2005. 
the complaint on a number of jurisdictional grounds, ${ }^{28}$ and alternatively because trying the case would allegedly require the revelation of classified information that could "cause exceptionally grave or serious damage to the intelligence, foreign policy, and national security interests of the United States." 29 If the district court accepts either of these arguments Arar's case will be dismissed before discovery, whether or not Arar's allegations are true and whether or not what happened to him is legal.

Out of court, the administration has argued that Arar's deportation was legal because it obtained promises from Syria that he would not be tortured, and cited the Syian government's subsequent denials that Arar was tortured. ${ }^{30}$ The United States seeks similar "diplomatic assurances" not to torture before every rendition, and the administration has repeatedly argued that obtaining these assurances is enough to meet the United States' obligations under the Torture Convention. Attorney General Alberto Gonzales wrote in response to questions from the Senate during his confirmation hearings that "assurances from a country that it will not engage in torture... can provide a basis for concluding that a person is not likely to be tortured if returned to another country." ${ }^{31}$ President George W. Bush ${ }^{32}$ and White House spokesman Scott McClellan ${ }^{33}$ have also cited assurances in defending the practice of rendition. The Bush administration has

\footnotetext{
${ }^{28}$ Memorandum in Support of Government's Motion to Dismiss, Arar v. Ashcroft, filed Sept. 17, 2004 (E.D.N.Y.) (No. CV-00249). See also, e.g., Memorandum in Support of John Ashcroft's Motion to Dismiss, Arar v. Ashcroft, filed Oct. 4, 2004 (E.D.N.Y.) (No. CV-00249). The other individual defendants' legal claims are quite similar to Ashcroft's.

29 Declaration of James B. Comey, Arar v. Ashcroft, filed Jan. 18, 2005 (E.D.N.Y.) (No. CV-00249), at 9 6. See also Memorandum in Support of the United States' Assertion of State Secrets Privilege, Arar v. Ashcroft, filed Jan. 18, 2005 (E.D.N.Y.) (No. CV-00249).

${ }^{30}$ For example, on November 20, 2003, Attorney General John Ashcroft told Canadian reporters that "[i]n removing Mr. Arar from the U.S., we acted fully within the law and applicable international treaties and conventions" and noted Syria's denials that Arar was tortured as "fully consistent with the assurances that the United States government received prior to the removal of Mr. Arar." Tim Harper, Arar Deportation “Within Law": Ashcroft, TORONTO STAR, Nov.21, 2003, at A13.

${ }^{31}$ Responses of Alberto Gonzales, Nominee to be Attorney General, to the Written Supplemental Questions of Senator Richard Durbin (Jan. 2005) (copy on file with author).

32 At a press conference on March 16, 2005, President Bush told reporters that suspects are only rendered "with the promise that they won't be tortured. That's the promise we receive. This country does not believe in torture. We do believe in protecting ourselves. We don't believe in torture." President George W. Bush, Press Conference (Mar. 16, 2005) (transcript available at http://www.whitehouse.gov/news/releases/2005/03/20050316-3.html).

33 McClellan told reporters on March 17, 2005 that “[w] hen people are rendered to another country, we seek assurances that they won't be tortured....We believe in adhering to our laws and our treaty obligations.” White House Press Secretary Scott McClellan, Press Briefing (Mar. 17, 2005) (transcript available at http://www.whitehouse.gov/news/releases/2005/03/20050317-4.html).
} 
maintained that Maher Arar's deportation complied fully with these laws, because the United States obtained diplomatic assurances from Syria that Arar would not be tortured. ${ }^{34}$

This Article will put aside the procedural and jurisdictional questions that may well decide Arar's lawsuit, in order to address the substance of his charges and the administration's defenses.

Section I will examine the publicly reported facts about Arar's rendition, which provide strong corroboration for thecharges in his complaint.

The rest of the paper will address the argument that rendition is legal as long as the CIA obtains diplomatic assurances from foreign governments that they will not torture prisoners. Section II will describe the two basic limits that the Convention Against Torture and its implementing legislation and regulations place on prisoner transfers: the United States cannot render prisoners to countries where they are more likely than not to face torture, and must consider all relevant evidence in determining whether the odds of torture after a rendition are greater than fifty percent.

Section III is an exhaustive survey of the publicly known factual evidence about the danger of torture after a rendition.

Section IV will argue that this evidence, which the CAT forbids the administration from ignoring, shows that the odds of torture after a rendition are much higher than fifty percent and that diplomatic assurances are legally worthless.

\section{AHMAD EL-MAATI, ABDULLAH ALMALKI, AND MAHER ARAR}

Maher Arar was not the first Canadian citizen interrogated and tortured in Syria about his alleged 
al-Qaeda ties in the wake of September 11. Ontario residents Ahmad Abou el-Maati and Abdullah Almalki were arrested in Syria before Arar. ${ }^{35}$ Unlike Arar, el-Maati and Almalki traveled to Syria voluntarily; they were not "rendered" by the United States. But their cases are relevant in understanding the relationship between the U.S. and Syrian intelligence services, the basis for sending Arar to Damascus, and the likelihood that the United States knew he would be tortured there. Arar was probably deported partly on the basis of evidence that Almalki and el-Maati gave under torture in Syria.

Ahmad el-Maati, a truck driver from Toronto, was the first to be arrested. In August of 2001, U.S. border guards stopped and searched el-Maati's truck. Inside they found "a schematic map of Ottawa marking government buildings and nuclear research facilities." 36 El-Maati said the map had been left in the glove compartment by another driver. He was released after eight hours of interrogation, but Canadian Security Intelligence Service (“CSIS") officials kept him under surveillance after he returned to Toronto. ${ }^{37}$ El-Maati has sworn in an affidavit that CSIS agents questioned him shortly after the September 11 attacks, and threatened that "they would stop the [immigration] sponsorship of my Syrian wife" if he did not cooperate. ${ }^{38}$

In addition to the map incident, Canadian officials may have suspected el-Maati because he had trained with an Afghan mujahideen militia in the early 1990s, had taken flying lessons near an airport in Toronto, ${ }^{39}$ and because his brother, Amer el-Maati, is on the FBI's terrorism wanted

\footnotetext{
35 There is actually a fourth Canadian citizen arrested and reportedly tortured in Syria, Arwad al-Buchi. But al-Buchi resided in Saudi Arabia for six years before his arrest in July 2002, and there does not appear to be any direct connection between his imprisonment and Arar's. Al-Buchi is still in Syrian custody. See Press Release, Syrian Human Rights Commission, Urgent Call to Release Arwad Al-Buchi (Nov. 14, 2003) (available at http://www.shrc.org/english/appeals/2003/14112003/14112003.htm); Michelle Shepard, Ex-Ottawa Man Held in Syria for Two Years, TORONTO STAR, Oct. 22, 2004, at A2.

36 Colin Freeze, Arar Case Began Amid Fear of Attack on Ottawa, GloBE \& MAIL, Jan. 16, 2004.

${ }^{37} \mathrm{Id}$.

38 Colin Freeze, Arar Accuser Says He Was Tortured, GLOBE \& MAIL, Apr. 29, 2004. El-Maati was then legally married to the woman for the purposes of immigration sponsorship, but the religious ceremony, reception and consummation of the marriage was planned to take place in November in Syria. Jeff Sallott, Once A Muhajed Who Took Flying Lessons, Ahmad El Maati Seemed toFit the Profile of a Terrorist, GLOBE \& MAIL, Aug. 29, 2005.

${ }^{39}$ See Jeff Sallott, Once A Muhajed Who Took Flying Lessons, Ahmad El Maati Seemed toFit the Profile of a Terrorist, GLOBE \& MAIL, Aug.
} 
list. ${ }^{40}$

In November 2001, el-Maati flew to Syria for his wedding ceremony and reception.

According to his affidavit, Canadian police or intelligence officials questioned him in the Toronto airport, and kept him under surveillance on the plane. ${ }^{41}$ When he arrived in Syria on November 12, he was arrested at the airport. ${ }^{42}$ He was taken to the Palestine Branch and held in a tiny, underground cell. ${ }^{43}$

El-Maati has charged that Syrian prison guards forced him to lie naked while they poured ice water on him, burnt him with cigarettes, and beat him with cables, until he agreed to sign "a false confession of false events...I signed and fingerprinted in order to stop the vicious and constant torture." $44 \mathrm{He}$ told interrogators that he and his brother ${ }^{45}$ were planning to blow up Canada's Parliament, and that two casual acquaintances of his, Abdullah Almalki and Maher Arar, were also involved in the plot. ${ }^{46}$

El-Maati was transferred from Syrian to Egyptian custody in January of 2002.47 He has said that Egyptian interrogators, like those in Syria, had information about him that only could have come from Canadian intelligence. They also practiced torture. At a prison outside Cairo "[a]n electric prod was used on [el-Maati's] hands, legs and genitals during interrogations. His hands were cuffed so tightly that his wrists bled." 48 In July of 2002 he was transferred to another Egyptian security facility, where

$29,2005$.

40 "FBI Seeking Information: Amer El-Maati", at http://www.fbi.gov/terrorinfo/el-maati.htm (last accessed Feb. 13, 2005). In November of 2001, a document granting Amer el-Maati Canadian citizenship was discovered in an al-Qaeda safe house in Kabul, Afghanistan. Cam Simpson, U.S. Seeks Help in Finding Terror Suspect, CHICAGO TRIBUnE, Nov. 12, 2002.

${ }^{41}$ Colin Freeze, Arar Accuser Says He Was Tortured, GloBE \& MAIL, Apr. 29, 2004.

42 Id.

43 See Jeff Sallott, Once A Muhajed Who Took Flying Lessons, Ahmad El Maati Seemed toFit the Profile of a Terrorist, GLOBE \& MAIL, Aug.

29, 2005. The article does not name the Palestine Branch but says that el-Maati was held at the same facility as Maher Arar.

44 Colin Freeze, Arar Accuser Says He Was Tortured, GloBE \& MAIL, Apr. 29, 2004.

45 Id.

46 Michelle Shepard, Untangling Tale of Tortured Canadian, TORONTO STAR, May 1, 2004, at A1.

47 Michelle Shepard, Egyptians Free Canadian Man, ToronTo STAR, Jan. 16, 2004, at A19.

48 Jeff Sallott, Once A Muhajed Who Took Flying Lessons, Ahmad El Maati Seemed toFit the Profile of a Terrorist, GLOBE \& MAIL, Aug. 29, 
He was kept blindfolded and handcuffed in a hallway with other prisoners for what he estimates was about two weeks. It was during this time, Mr. El Maati says, that he developed anal bleeding. Canadian doctors later diagnosed an anal fissure requiring surgery. ${ }^{49}$

El-Maati told the Globe and Mail that he was first allowed to see a Canadian consul on

August 12, 2002. During this visit

The Egyptians were present, so Mr. El Maati felt he could not talk freely about his treatment by the Egyptian authorities. But he decided to take a chance, and says he blurted out about how the Syrians had tortured him....He says he used the word torture, not a euphemism. He says he saw them write the word down. He says he specified that he had been beaten with a cable. ${ }^{50}$

Canadian government documents from August 2002 show that the Royal Canadian Mounted

Police ("RCMP") discussed "a proactive measure to discuss media lines to be used when Ahmad

El-Maati's allegations about torture" became public. ${ }^{51}$

Egypt released el-Maati in January 2004,52 and he returned to Canada two months later. ${ }^{53} \mathrm{He}$

was never charged with anything in Canada, and a Canadian newspaper reported shortly after el-

Maati's release that "[h]is Middle Eastern captors no longer regard him as a suspect." 54 A

Canadian government official told the same newspaper that "I would say the chance of it [a plot] being likely was 35 per cent, and 65 per cent not....I know a lot of people don't believe this, but we are involved in a war -- it's called a war on terror. And in any kind of war, innocents are hurt." 55

Abdullah Almalki, an engineer from Ottawa, was the second Canadian to be arrested in Syria. Almalki had been under the surveillance by Canadian intelligence since 1998, when he told a CSIS agent that he once worked for a non-profit refugee resettlement program in Pakistan whose administrator, Ahmed Said Khadr, had ties to al-Qaeda. ${ }^{56}$ Almalki later sold components for

\footnotetext{
2005.

$49 \mathrm{Id}$.

${ }^{50} \mathrm{Id}$.

${ }_{52}^{51}$ Colin Freeze, Mounties Warned Against Release of Arar, GLoBE \& MAIL, Nov. 27, 2004.

$52 \mathrm{Id}$.

53 Canadian Returns After Long Ordeal in Syrian and Egyptian Jails, CANADIAn Press NewswiRe, Mar. 30, 2004

${ }^{54}$ Freeze, Arar Case Began Amid Fear of Attack on Ottawa, GLOBE \& MAIL, Jan. 16, 2004.

${ }^{55} \mathrm{Id}$.

56 Jeff Sallott, For the First Time, Abdullah Almalki Tells His Story, GLoBE \& MAIL, Aug. 27, 2005.
} 
radio equipment to the Pakistani military; he has said this equipment could not be used in weaponry and was not illegal to export. ${ }^{57}$ Almalki has stated that he cooperated fully with authorities every time they questioned him, but he continued to receive increased scrutiny at airports and from the Customs Bureau, and the CSIS questioned Almalki's acquaintances about him several times. ${ }^{58}$ He was interviewed by a CSIS officer a week after the September 11 attacks, and he and his wife believed they were being followed by police or intelligence agents. ${ }^{59}$

In October 2001, Arar and Almalki had lunch in a restaurant in Ottawa. The Globe and Mail has reported that "[d]ocuments filed at the Arar commission say this was the first time Mr. Arar came to the attention of the RCMP anti-terrorist investigators." 60 In late November, partly out of frustration with this scrutiny, Almalki and his family began a long visit with his wife's relatives in Malaysia. ${ }^{61}$

In May 2002, Abdullah Almalki traveled to Syria to visit a sick grandmother. He was taken into custody when he arrived at the Damascus airport on May 3, 2002.62

Almalki, like Arar and el-Maati, has described being imprisoned in an underground cell that was approximately one meter wide, two meters long, and two meters high. ${ }^{63} \mathrm{He}$ was held there for 482 days. ${ }^{64}$ Almalki told the Globe and Mail that he was tortured severely. On the first day, "he remembers one of the torturers standing on his back while another lashed the soles of his feet with a thick, twisted cable...The pain was so intense, he says, he lied to stop the beatings....He

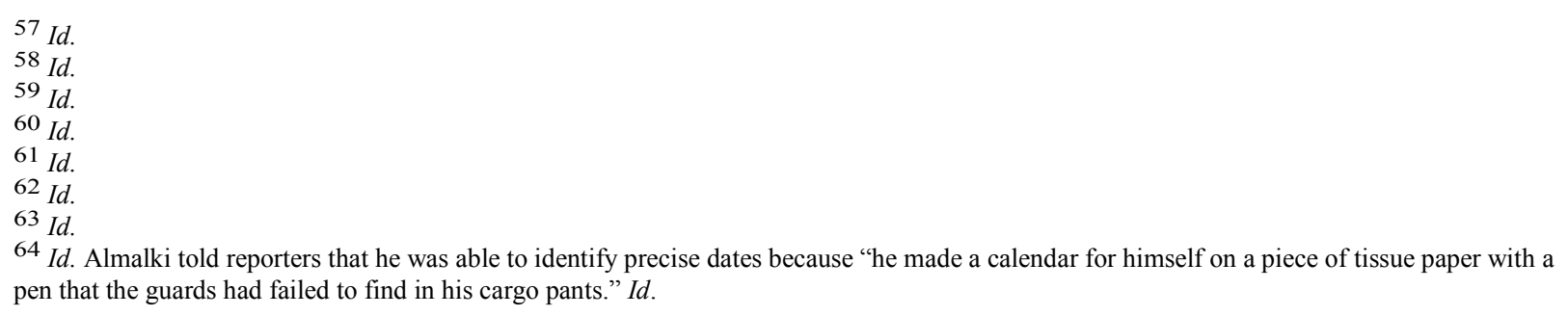


says his interrogators told him he had endured more than a thousand lashes" 65 Two days later,

he was stripped down to his underwear, blindfolded, bent over and stuffed into a tire with his backside sticking out one side and his head and lower legs sticking out the other. He says the torturers raised his legs so his weight was on his back on the floor and he could not move. They beat him on the soles of his feet, his head, torso, and genitals. ${ }^{66}$

On July 18,2002 , he was beaten for most of the day with metal cables, and tied to and suspended from a metal window frame with a piece of rag, and then untied and beaten again until

"he could not move or feel his hands." 67

These descriptions, which Almalki gave to reporters in August 2005, are quite similar to Maher Arar's account of Almalki's treatment in November 2003. Maher Arar told Canadian reporters that when he encountered Almalki in Syria's Sednaya prison on September 19 or 20, 2003:

I did not recognize him. His head was shaved, and he was very, very thin and pale. He was very weak. When I looked closer, I recognized him. It was Abdullah Almalki....He told me he had been severely tortured -- with the tire, and the cable. He was also hanged upside down. He was tortured much worse than me. He had also been tortured when he was brought to Sednaya, so that was only two weeks before. ${ }^{68}$

Amnesty International reported on November 4, 2003, probably based on information from

Arar, that

Abdallah al-Malki has reportedly been subjected to a form of torture known as the dullab, which involves hanging the victim from a suspended tyre and beating him or her with sticks and cables. He has apparently also been given electric shocks and has been beaten around his body with cables as well as kicked in the head. ${ }^{69}$

During these interrogations, Almalki was repeatedly asked about information that he believed

could only have come from Canadian police or intelligence. Interrogators several times referred to information as coming from Canadian reports or Canadian officials, and once told Almalki that Canadian intelligence had asked to question Almalki directly. ${ }^{70}$

Almalki described being interrogated about Maher Arar on at least two occasions. On the

\footnotetext{
$65 I d$.

${ }^{66} \mathrm{Id}$.

$67 \mathrm{Id}$.

68 Maher Arar, Statement to the Media (Nov. 4, 2003) (transcript available at http://www.cbc.ca/news/background/arar/arar_statement.html).

69 Press Release, Amnesty International, Syria: Fear of Torture and Ill-Treatment/Unlawful Detention/Incommunicado Detention/Ill-Health, Abdallah al-Malki (Nov. 4, 2003) (available at http://web.amnesty.org/library/Index/ENGMDE240382003?open\&of=ENG-376).
} 
fortieth day of Almalki's interrogation, Syrian intelligence officials began a series of "new questions about a specific list of about 20 people from Canada, including Mr. Arar."71 Almalki has alleged that later on, four days after Arar was detained at JFK airport and before Arar's deportation to Syria, he was brought up for an interrogation that focused on Arar. ${ }^{72}$ If this is accurate it strongly suggests that Syria was interrogating Almalki about Arar at the United States' request.

Abdullah Almalki's wife Kuzimah Khalifa and his brother Youssef told Canadian reporters that when released from prison in March 2004, Almalki suffered from an improperly healed broken foot, an injured hip, back pain, balance problems, impaired memory and concentration, and posttraumatic stress disorder. ${ }^{73}$ In July 2004, a Syrian judge acquitted Almalki of all terrorism-related charges but ordered him to perform thirty months of compulsory service in the Syrian military. ${ }^{74}$ This order was either rescinded, not enforced, or disobeyed; Almalki returned to Canada the next month. ${ }^{75}$ He has not been charged with any crime.

Arar's relationship with Almalki and el-Maati seems to have been the main reason or only reason for his deportation. According to the Globe and Mail, Canadian government documents show that the RCMP regarded Arar as merely a "peripheral" and "secondary" figure, or a "potential witness," in their terrorism investigations. ${ }^{76}$ As noted above, in April 2002, before Almalki's arrest, Arar successfully renewed a U.S. work permit. After Almalki’s arrest, airport officials not only would not admit Arar to the United States; they considered him too great a security risk to let him return to Canada or deport him to Switzerland. During Arar's initial interrogation at JFK airport on September 26, U.S. intelligence officials focused

\footnotetext{
70 Jeff Sallott, For the First Time, Abdullah Almalki Tells His Story, GLoBE \& MAIL, Aug. 27, 2005.

71 Id.

72 Id.

73 See Michelle Shepard, Ottawa Engineer Acquitted in Syria, ToRONTO STAR, July 27, 2004, at A1; Canuck in Syria Seeks Help, WinNIPEG Sun, July 28, 2004, at 10 .

74 Michelle Shepard, Ottawa Engineer Acquitted in Syria, TORONTO STAR, July 27, 2004, at A1.

75 Kate Jaimet, Ottawa Man Held in Syria Returns Home, OTTAwA CiTIZEN, Aug. 10, 2004

76 Colin Freeze, Mounties Warned Against Release of Arar, GLOBE \& MAIL, Nov. 27, 2004.
} 
heavily on his relationship with Abdullah Almalki. When Arar said that they were only casual acquaintances -- Almalki was the brother of a co-worker and they had had lunch together once in October, 2001 -- interrogators began "yelling at me that I had a selective memory" and produced a copy of Arar's apartment lease that was witnessed by Abdullah Almalki in 1997.77 Arar's interrogation sessions in Syria centered on his relationship with Abdullah Almalki. ${ }^{78}$ Arar was also questioned about Ahmed el-Maati, whom he said he knew even less well than Abdullah Almalki. Arar later told the Toronto Star that "I saw [el-Maati] at a garage in Montreal, that was about four years ago. I don't remember everything we talked about, nothing special." 79

Arar's relationship with Almalki and el-Maati was the "only stated reason" the INS gave in its October 2002 decision ordering Arar's deportation to Syria. ${ }^{80}$ INS Eastern Region Director J. Scott Blackman wrote that:

I have determined that Arar is a member of the designated foreign terrorist organization known as al-Qaeda. The FBI interviewed Arar on September 27, 2002, at JFK International Airport. During the interview, Arar admitted his association with Abdullah Almalki. ${ }^{81}$

The decision noted Arar's October 2001 lunch meeting with Almalki, and said that Arar "advised the FBI that Almalki exports radios and that one of his customers was the Pakistani military." 82 It gave no details about Arar's alleged relationship with el-Maati, stating only that "[d]uring the September 27, 2002, interview at JFK, Arar admitted knowing Ahman [sic] ElMaati." 83

\footnotetext{
${ }_{77}$ Maher Arar, Statement to the Media (Nov. 4, 2003) (transcript available at http://www.cbc.ca/news/background/arar/arar_statement.html).

78 Plaintiff's Complaint, Arar v. Ashcroft, supra note 1, at 95.

79 Michelle Shepard, Untangling Tale of Tortured Canadian, TOROnTO STAR, May 1, 2004, at A1.

80 Colin Freeze, U.S. Cited Acquaintances in Deporting Arar, GLOBE \& MAIL, Jan. 23, 2004.

${ }^{81} \mathrm{Id}$.

$82 \mathrm{Id}$.

${ }^{83}$ Id. Blackman's decision does refer to a "classified addendum" providing further information about Arar, but I think that most likely contains information from Almalki's and el-Maati's interrogations in Syria. I should emphasize that this has not been confirmed, it is only my best working hypothesis. It is supported not only by Almalki's and el-Maati's descriptions of being tortured and interrogated about Arar, but also by the legal documents the government filed in Arar v. Ashcroft, asking the court to dismiss Arar's suit because it would require the disclosure of state secrets. See Memorandum in Support of the United States' Assertion of State Secrets Privilege [hereinafter 'Defendants' State Secrets Privilege Memorandum"], filed Jan. 18, 2005; Declaration of Tom Ridge [hereinafter "Ridge Declaration"], filed Jan. 17, 2005, Arar v. Ashcroft. (E.D.N.Y.) (No. CV-00249). The memorandum makes it clear that the assertion of states secret privilege relates to the classified addendum to Blackman's decision. See Defendant's State Secrets Privilege Memorandum at 8 - 9. Former Homeland Security Secretary Tom Ridge's declaration states that the material in that classified addendum: relates to the United States' intelligence activities and intelligence information regarding the plaintiffs. It contains
} 
Blackman's decision is one of many government documents and other independent sources that corroborate Arar's allegations about his deportation and torture:

- A Canadian government study on the CSIS's role in Arar's deportation contains an excerpt from the Canadian Foreign Affairs Ministry's initial summary of the Arar case, which gives the same dates as Arar's legal complaint for Arar's detention, meetings with the Canadian consul and his attorney, INS hearing, disappearance from the Brooklyn Metropolitan Detention Center, and appearance in Syria. ${ }^{84}$

- Canadian Consul Maureen Girvan met with Arar in New York on October 3. Girvan's notes on the meeting, written shortly afterwards, show that Arar told her that the United States had threatened to deport him to Syria. ${ }^{85}$

- Amal Oummih, Arar's attorney, has said the INS gave her false information about Arar's whereabouts in the days immediately before he was taken to Syria. Shortly after Arar's deportation Oummih told the Boston Globe, "They told me there was a hearing, but they never notified me... They won't tell me where he was deported to. I kept asking and finally [an INS official] told me, 'You won't find him in the U.S." 86

- Canadian government documents indicate that U.S. officials did not give Canadian diplomats truthful information about Arar's whereabouts while he was being deported to Syria. A declassified Canadian government memo states that U.S. authorities told

numerous references to intelligence sources and methods, the disclosure of which reasonably could be expected to cause exceptionally grave or serious damage to the national security of the United States and its foreign relations or activities. Disclosure of this information would enable adversaries of the United States to avoid detection by the nation's intelligence activities, sources, and methods, and/or take measures to defeat or neutralize those activities, thus, causing extremely grave or serious damage to the United States' national security interests. In addition, disclosure of the information relied upon to reach each of the three noted decisions would post an exceptionally grave or serious risk to diplomatic relations and national security.

Ridge Declaration at 95.

84 Security Intelligence Review Committee, The Role of CSIS In the MAtTer of Maher Arar 14-15 (May 19, 2004).

85 Michelle Shepard, Arar Requests Hearing in Public, ToRonto STAR, Sept. 24, 2004, at A14.

${ }^{86}$ Cindy Rodriguez, Mystery Surrounds U.S. Deportation of Canadian, Boston GloBE, Oct. 18, 2002, at A31. 
Canadian consular officials on October 7, 2002 that Arar would have a deportation hearing later that day, and Canadian officials believed he would be represented by a lawyer there. In fact the hearing took place late at night on October 6, and Arar's lawyer was not told about it until after it had happened. ${ }^{87}$ On October 8 , Canadian officials called the Brooklyn Metropolitan Detention Center, and were "advised that Mr. ARAR was not longer there. American officials refused to provide any information as to where Mr. ARAR [was]...it was not until October $10 \ldots$ that American officials confirmed that $\mathrm{Mr}$. ARAR had been deported to Syria." $" 88$

- The final order deporting Arar to Syria was signed by then-Deputy Attorney General Larry D. Thompson, the second highest ranking official in the Department of Justice. ${ }^{89}$

- Arar has described being placed in a small private jet in an airfield in New Jersey, and flown to Washington, D.C., Portland, Maine, Rome, and finally to Amman Jordan. ${ }^{90}$ Federal aviation records obtained by The New York Times show that on the night of Arar's deportation, a Gulfstream III Jet chartered by the CIA with the tail number N829MG flew from New Jersey, to Dulles International Airport in Washington D.C., to Bangor, Maine, to Rome. ${ }^{91}$ (The records only show flights that begin or end in the United States, and so do not include any flight from Rome to Jordan. $)^{92}$

- A document outlining the strategy for Canada's Security Intelligence Review Committee's inquiry into the Arar case stated that the committee would investigate "[Arar] being held

\footnotetext{
87 Jeff Sallot, Chrétien Was Kept in the Dark About Arar, GloBE \& MAIL, Jan. 9, 2004.

88 SECURITy InTELligenCE REVIEW COMMITTEE, THE Role OF CSIS IN THE MATTER OF MAHER ARAR 14-15 (May 19, 2004 ).

89 Dana Priest, Top Justice Aide Approved Sending Suspect to Syria, WASH. Post, November 19, 2003, at A28, available at http://www.washingtonpost.com/ac2/wp-dyn?pagename=article\&node=\&contentId=A59678 - 2003Nov18\&notFound=true.

${ }^{90}$ DeNeen Brown, Ex-Detainee Details Fearful Path to Syria; Torture Followed Handover By American 'Removal' Unit, WasH. Post, Nov. 12,2003 , at A14.

91 Scott Shane, Suit by Detainee on Transfer to Syria Finds Support in Jet's Log, N.Y. TimES, Mar. 29, 2005 , at A1.

92 Id.
} 
at a CIA debriefing station in Jordan." 93

- The Israeli newspaper Ha'aretz has reported that the CIA is operating a secret interrogation center for eleven high level al-Qaeda suspects in Jordan, according to "anonymous international intelligence sources... involved in interrogating the detainees."94 Arar has described being briefly held and questioned in a prison in Jordan ${ }^{95}$ where he was taken between floors on an elevator. He told the Toronto Star, "it is very strange to find prisons with elevators in the Middle East. This place was not like the Syrian prisons."96

- A December 2002 briefing note on the Arar case for the Canadian Minister of Foreign Affairs stated that Arar was "accompanied by U.S. and Jordanian officials" (emphasis added) when taken into Syrian custody. ${ }^{97}$

- The State Department's 2001 - 2004 Country Reports on Human Rights Practices for Syria describe severe and widespread torture by the country's intelligence service. ${ }^{98}$ The 2004 report states:

According to Amnesty International (AI) and the Human Rights Association of Syria, there were eight persons who died in detention due to torture or mistreatment by the security services during the year.... Former prisoners and detainees, as well as the HRAS, reported that torture methods included administering electrical shocks; pulling out fingernails; forcing objects into the rectum; beating, sometimes while the victim was suspended from the ceiling; hyperextending the spine; bending the detainees into the frame of a wheel and whipping exposed body parts; and using a backward-bending chair to asphyxiate the victim or fracture the victim's spine. Torture was most likely to occur while detainees were being held at one of the many detention centers run by the various security services throughout the country, particularly while the authorities were attempting to extract a confession or information. ${ }^{99}$

- The details of Arar's description of his detention and torture in Syria are consistent with

\footnotetext{
93 Michelle Shepard, Arar May Have Spent Time at Secret CIA Facility, TORONTO STAR, Oct. 15, 2004.

94 Yossi Melman, CIA Holding Al-Qaida Suspects in Secret Jordanian Lockup, HA’ARETZ, Oct. 13, 2004.

95 Maher Arar, Statement to the Media (Nov. 4, 2003) (transcript available at http://www.cbc.ca/news/background/arar/arar_statement.html).

96 Michelle Shepard, Arar May Have Spent Time at Secret CIA Facility, ToronTO StAR, Oct. 15, 2004.

97 Id.

98 U.S. Department of State, Country Reports on Human Rights Practices: Syria -- 2004 (Feb. 2005); U.S. Department OF State, COUNTRY REPORTS ON HUMAN RightS PRACTICES: SYRIA -- 2003 (Feb. 2004); U.S. DEPARTMENT OF STATE, COUNTRY REPORTS ON HUMAN

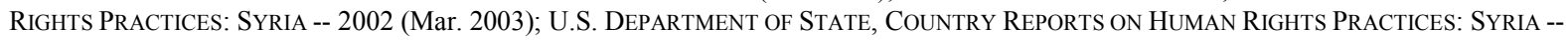
2001 (Mar. 2002). All of the State Department's Country Reports from 1993 - 2004 are available at http://www.state.gov/g/drl/hr/c1470.htm.

99 U.S. DePARTMENT OF STATE, COUNTRY REPORTS ON HuMAN RightS PRACTICES: SyRia -- 2004 (Feb. 2005),

http://www.state.gov/g/drl/rls/hrrpt/2004/41732.htm.
} 
human rights groups' reports on conditions in Syrian prisons. For example, Arar stated that on his first day of interrogation at the Palestine Branch, "If I did not answer quickly enough, [the interrogator] would point to a metal chair in the corner and ask 'Do you want me to use this?" "100 Human rights groups' reports on Syria frequently describe a torture device known as the "German Chair", described as "a metal chair with moving parts which stretches the spine and causes severe pressure on the neck and legs." ${ }^{101}$ Amnesty International's 2002 report on Syria describes prisoners being tortured with the German Chair and being beaten with cables at the Palestine Branch. ${ }^{102}$ A separate Amnesty International press alert refers to "the tiny, underground cells referred to as 'tombs' or 'graves' by the detainees and prison guards" in the Palestine branch, and describes conditions very similar to what Arar said he experienced. ${ }^{103}$

- As noted above, Arar, el-Maati and Almalki gave consistent descriptions of conditions in the Palestine Branch and the torture methods used by interrogators there.

- In August of 2003, before Arar's release, the Syrian Human Rights Committee ("SHRC") wrote in a letter to Arar's wife that according to "confirmed reports from confidential and knowledgeable sources," Arar had "received heavy and severe torture" in Syria. ${ }^{104}$

- On October 4, 2003, Arar told the press that he had falsely confessed under torture in Syria to attending an al-Qaeda training camp in Afghanistan. ${ }^{105}$ The New York Times reported on November 15, 2003 that "American officials who spoke on condition of

\footnotetext{
100 Maher Arar, Statement to the Media (Nov. 4, 2003) (transcript available at http://www.cbc.ca/news/background/arar/arar_statement.html).

101 E.g., AMNESTY INTERNATIONAL, ANNUAL REPORT 2002: SYRIA (2002), http://web.amnesty.org/web/ar2002.nsf/mde/syria?Open.

$102 \mathrm{Id}$.

103 Press Release, Amnesty International, Appeal Case -- Syria: Syrian German Held Three Years Without Charge in Rat-Infested Syrian "Tomb" (Oct. 8, 2004) (available at http://web.amnesty.org/library/pdf/MDE240662004ENGLISH/\$File/MDE2406604.pdf).

104 Foreign Affairs Says Arar Not Being Tortured, CTV.CA NEwS, Aug. 14, 2003,

http://www.ctv.ca/servlet/ArticleNews/story/CTVNews/1060877244853_100?s_name=\&no_ads=. The letter is not perfectly consistent with Arar's description of his own torture; SHRC alleged that Arar had been tortured with "beating by sticks and shredded cables on the sole of his feet and on his body, the use of electricity and being squashed in a car tire for long hours, etc.," allegations that Arar himself did not make after
} 
anonymity... say [Arar] confessed under torture in Syria that he had gone to Afghanistan

for terrorist training, named his instructors and gave other intimate details."106

- According to Canadian government documents, Francisco Pillarella, Canada's

ambassador to Syria, was given a written and "verbal briefing of the results of the

Syrians' investigation of Arar" in November of 2002. ${ }^{107}$ He passed the information to the

CSIS, ${ }^{108}$ which later leaked the details of the confession Arar made in Syria to Ottawa

Citizen reporter Juliet O’Neill. ${ }^{109}$

- Syrian diplomat Imad Moustapha told 60 Minutes II that Syria had shared its reports about Arar with American intelligence, and that "[w]e always share information with anybody alleged to be in close contact with al-Qaeda with the United States."110

- In another known case of rendition to Syria, U.S. officials told Time magazine that American agents in Damascus were submitting written questions for Syrian interrogators to ask al-Qaeda suspect Muhammad Haydar Zammar, and receiving reports of the interrogation sessions. ${ }^{11}$ "State Department officials like the arrangement," Time reported, "because it insulates the U.S. government from any torture the Syrians may be applying to Zammar."112 Zammar, like Arar, was held in an underground, tomb-like cell in the Palestine Branch. ${ }^{113}$

his release. Id. However, it remains another piece of evidence that Arar was tortured in Syria.

105 Maher Arar, Statement to the Media (Nov. 4, 2003) (transcript available at http://www.cbc.ca/news/background/arar/arar_statement.html).

106 Clifford Krauss, Qaeda Pawn, U.S. Calls Him. Victim, He Calls Himself, N.Y. Times, November 15, 2003, at A4.

107 SeCurity InTELLIGENCE ReVIEW COMMITtee, THE Role OF CSIS IN THE MATtER OF MAHER ARAR 18 (May 19, 2004); see also Michelle Shepard, Ambassador Gave Syrian Information to CSIS, TORONTO STAR, Sept. 14, 2004, at A4.

108 SeCurity InTELligence ReVIEW COMmitTeE, THE ROLE OF CSIS IN THE MATtER OF MAHER ARAR 18 (May 19, 2004).

109 See Juliet O'Neill, Canada's Dossier on Maher Arar, OtTAWA CitıZEn, November 8, 2003.

11060 Minutes II: His Year in Hell (CBS television broadcast, Mar. 30, 2004, transcript available at

http://www.cbsnews.com/stories/2004/01/21/60II/main594974.shtml).

111 Mitch Frank, Help From an Unlikely Ally, Time, July 1, 2002.

112 Id.

113 The details of Zammar's rendition, interrogation and imprisonment are discussed further in Section III(B)(2)(a), infra. 
Arar has given a consistent, detailed description of his experience since he first spoke to reporters in October 2003. It has been corroborated by independent sources over and over again, including government documents and flight records that only became public long after Arar first made his allegations. There is little doubt that the factual charges in his complaint are true.

\section{THE LEGAL STANDARD FOR EVALUATING DIPLOMATIC ASSURANCES NOT}

\section{TO TORTURE}

Arar's lawsuit alleges that his deportation to Syria violated Article 3 of the United Nations

Convention Against Torture and Other Cruel, Inhuman or Degrading Treatment or Punishment. Article

3 states that:

1. No State party shall expel, return ("refouler") or extradite a person to another state where there are substantial grounds for believing that he would be in danger of being subjected to torture.

2. For the purpose of determining whether there are such grounds, the competent authorities shall take into account all relevant considerations including, where applicable, the existence in the State concerned of a consistent pattern of gross, flagrant or mass violations of human rights. ${ }^{114}$

The Senate ratified the Convention Against Torture subject to the understanding that the phrase "substantial grounds for believing that he would be in danger of being subject to torture" would be interpreted "to mean "if it is more likely than not that he would be tortured."'115

The treaty is not self-executing. ${ }^{116}$ Article 3 was incorporated into U.S. law by section 2242 of the 1998 Foreign Affairs Reform and Restructuring Act ("FARRA"), which provides in part:

(a) Policy. It shall be the policy of the United States not to expel, extradite, or otherwise effect the involuntary return of any person to a country in which there are substantial grounds for believing the person would be in danger of being subjected to torture, regardless of whether the person is physically present in the United States.

(b) Regulations. Not later than 120 days after the date of enactment of this Act, the heads of the appropriate agencies shall prescribe regulations to implement the obligations of the United States under Article 3 of the United Nations Convention Against Torture and Other Forms of Cruel, Inhuman or Degrading Treatment or Punishment,

114 Convention Against Torture and Other Cruel, Inhuman or Degrading Treatment or Punishment, Dec. 10, 1984, S. Treaty Doc. No. 100 - 20 , 1465 U.N.T.S. 85.

115136 Cong. Rec. 36,193 (1990).

116 Id. 
subject to any reservations, understandings, declarations, and provisos contained in the United States Senate resolution of ratification of the Convention. ${ }^{117}$

The Bush administration has maintained that Maher Arar's deportation and every rendition complied fully with these laws, because the United States obtained diplomatic assurances from Syria that Arar would not be tortured, as it does before every rendition. According to the Washington Post, the procedure for obtaining assurances is brief and informal: the CIA station chief of the country where the prisoner is being rendered requests a verbal assurance from the foreign intelligence service, and then cables the assurance back to CIA headquarters. ${ }^{118}$ It is not clear what steps, if any, the U.S. takes to verify compliance with assurances.

There are no publicly available executive orders or CIA or Department of Defense regulations about how to evaluate diplomatic assurances or determine when a suspect is more likely than not to be tortured. There are federal immigration regulations and court decisions on the same subject, which apply directly in Arar's case and which are a useful comparison in other cases insofar as they correctly interpret the requirements that Article 3 imposes.

8 C.F.R. $\S \S 208.18(c)$ and $1208.18(c){ }^{119}$ say that the Secretary of State "may forward to the Attorney General" a country's assurances not to torture, and the Attorney General "shall determine, in consultation with the Secretary of State, whether the assurances are sufficiently reliable to allow the alien's removal to that country consistent with Article 3 of the Convention Against Torture." 120 This determination can be delegated to the Deputy Attorney General or the head of the immigration service, but not to anyone else. ${ }^{121}$ Asylum officers, immigration judges, and the Board of Immigration Appeals cannot review the Attorney General's decision to accept

\footnotetext{
117 Foreign Affairs Reform and Reconstruction Act of 1998, § 2242, Pub. L. No. 105 - 277, 112 Stat. 2681, 2681 - 822, codified as note to 8 U.S.C. § 1231 (1998).

118 Dana Priest, CIA's Assurances on Transferred Suspects Doubted, WASH. POST, Mar. 17, 2005, at A1, available at http://www.washingtonpost.com/wp-dyn/articles/A42072 - 2005Mar16.html.

119 The text of these provisions is identical.

120 8 C.F.R. § 208.18(c) (2004).

${ }^{121} I d$.
} 
assurances, ${ }^{122}$ and judicial review is barred except in the context of review of a final order of removal under the Immigration and Nationality Act. ${ }^{123}$ However, foreclosing judicial and administrative review does not change the Attorney General's obligation to comply with Article 3 of the Torture Convention as implemented by FARRA. $\S 208.18$ only authorizes the Attorney General to accept assurances if they are "sufficiently reliable"; 124 it does not provide any guidelines or standards for how the Attorney General shall evaluate their reliability.

8 C.F.R. $§ 208.16$ explains the general standard for withholding and deferral of removal under the Convention Against Torture in immigration cases. Subsection (c)(2) states that the applicant must prove that he or she is more likely than not to be tortured if sent to a country. ${ }^{125}$ The applicant's testimony can meet this burden without additional corroborating evidence, if it is found credible. ${ }^{126}$ Subsection (c)(3) provides that:

In assessing whether it is more likely than not that an applicant would be tortured in the proposed country of removal, all evidence relevant to the possibility of future torture shall be considered, including, but not limited to:

(i) Evidence of past torture inflicted upon the applicant;

(ii) Evidence that the applicant could relocate to a part of the country of removal where he or she is not likely to be tortured;

(iii) Evidence of gross, flagrant or mass violations of human rights within the country of removal, where applicable; and

(iv) Other relevant information regarding conditions in the country of removal. ${ }^{127}$

\section{A. “All Evidence Relevant to the Possibility of Future Torture Shall Be CONSIDERED."}

Stated as a negative, the requirement that "all evidence relevant to the possibility of future torture shall be considered" means that it is illegal to disregard any information about the likelihood of torture. The Second, Third, Fourth, Sixth Seventh, Eighth, and Ninth Circuits have all overturned Convention Against Torture decisions by immigration judges and the Board of

\footnotetext{
122 Id.

123 Id.

124 Id.

1258 C.F.R. $\S 208.16(c)(2)(2004)$.

$126 I d$.

1278 C.F.R. § 208.16(c)(3) (2004). Emphasis added.
} 
Immigration Appeals ("BIA") for failing to consider relevant evidence about the risk of torture. ${ }^{128}$

Article 3 of the CAT, 8 C.F.R. $\S 208.16$, and the court decisions implementing them all recognize that some of the most relevant evidence of the danger of torture is a country's human

rights record. Article 3 states that in evaluating the danger of torture in another country, "the competent

authorities shall take into account... the existence in the State concerned of a consistent pattern of gross, flagrant or mass violations of human rights. ${ }^{129}$ Accordingly, 8 C.F.R. $§ 208.16$ requires immigration

officials and judges to consider "[e]vidence of gross, flagrant or mass violations of human rights within the country of removal"130 in CAT cases. The Ninth Circuit stated in Kamalthas v. INS that "country conditions alone can play a decisive role in granting relief under the Convention [Against Torture].”131

The Third Circuit has agreed, ${ }^{132}$ and noted that the official human rights reports that the State Department publishes each year "are the most appropriate and perhaps the best resource" for determining country conditions. ${ }^{133}$ The Sixth, ${ }^{134}$ Seventh ${ }^{135}$ and Eighth ${ }^{136}$ Circuits have also overturned and remanded CAT

${ }^{128}$ E.g., Mostafa v. Ashcroft, 395 F. 3d 622 (6th Cir. 2005), Farah v. Ashcroft, 114 Fed. Appx. 325 (9th Cir. 2004), Hamoui v. Ashcroft, 389 F.3d 821 (9th Cir. 2004), Zewdie v. Ashcroft, 381 F.3d 804 (8th Cir. 2004), Camara v. Ashcroft, 378 F.3d 361 (4th Cir. 2004), Habtemicael v. Ashcroft, 370 F.3d 774 (8th Cir. 2004), Ramsameachire v. Ashcroft, 357 F.3d 169 (2nd Cir. 2004), Singh v. Ashcroft, 107 Fed. Appx. 799 (9th Cir. 2004), Zubeda v. Ashcroft, 333 F.3d 463 (3rd Cir. 2003), Castro-Gonzalez v. INS, 60 Fed. Appx. 705 (9th Cir. 2003), Kamalthas v. INS, 251 F.3d 1279 (9th Cir. 2001), Mansour v. INS, 230 F. 3d 902 (7th Cir. 2000). In most of these cases, the federal courts of appeal have concluded that the Board or Immigration Judge erred by failing to consider the alien's Convention Against Torture claim separately from his or her asylum claim. As the Ninth Circuit explained in Kamalthas v. INS, in a CAT case, unlike an asylum case, "a petitioner need not show that he or she would be tortured 'on account of a protected ground" such as race, religion, political opinion, nationality, or membership in a particular social group. Kamalthas v. INS, 251 F.3d at 1283. In addition, as the Second Circuit noted in Ramsameachire v. Ashcroft, to obtain asylum "the alien must establish, though credible testimony, either that he or she has suffered past persecution, or that he or she subjectively fears persecution." Ramsameachire v. Ashcroft, 357 F.3d at 185. In contrast, "to prevail on a CAT claim the alien need only proffer objective evidence that he or she is likely to be tortured in the future." Id. Therefore, circuit courts have consistently held that the BIA's finding that an applicant is not a credible witness or is not eligible for asylum does not excuse the BIA from carefully considering "all evidence relevant" to the danger of torture. Id. See also Hamoui v. Ashcroft, 389 F.3d 821 (9th Cir. 2004), Singh v. Ashcroft, 107 Fed. Appx. 799 (9th Cir. 2004), Zubeda v. Ashcroft, 333 F.3d 463 (3rd Cir. 2003), Castro-Gonzalez v. INS, 60 Fed. Appx. 705, 706 (9th Cir. 2003), Kamalthas v. INS, 251 F.3d 1279 (9th Cir. 2001), Mansour v. INS, 230 F. 3d 902 (7th Cir. 2000).

129 Convention Against Torture and Other Cruel, Inhuman or Degreading Treatment or Punishment, Dec. 10, 1984, S. Treaty Doc. No. 100 - 20, 1465 U.N.T.S. 85.

130 8 C.F.R. $\$ 208.16$ (2004).

${ }^{131}$ Kamalthas v. INS, 251 F.3d 1279, 1280 (9th Cir. 2001). See also Farah v. Ashcroft, 114 Fed. Appx. 325, 326 (9th Cir. 2004).

132 Zubeda v. INS, 333 F. 3d 463, 477 (3rd Cir. 2003) ("Official as well as unofficial country reports are probative evidence and can, by themselves, provide sufficient proof to sustain an alien's burden”). See also Tarrawally v. Ashcroft, 338 F.3d 180, 188 (3rd Cir. 2003).

${ }^{133}$ Zubeda v. INS, 333 F.3d at 478 (quoting Kazlauskaz v. INS, 46 F.3d 902, 906 (9th Cir. 1995), and Rojas v. INS, 937 F.3d 186, 190 n.1 (5th Cir. 1991)).

134 E.g. Mostafa v. Ashcroft, 395 F.3d 622, 624 - 6 (6th Cir. 2005) (vacating and remanding a decision because "the Board's opinion in this case contains absolutely no discussion of the country conditions in Iran," although the State Department's 1999 and 2000 Country Reports were included in the administrative record).

${ }^{135}$ E.g, Mansour v. INS, 230 F.3d 902, 908 - 9 (7th Cir. 2000) (overturning and remanding a decision in part because of the Board's failure to address a 1998 State Department Country Report on Iraq. "The Report is specific on the meaning and consequence of being part of the ethnic/religious group of Assyrian Christians and had the BIA addressed the Report it might have viewed Mansour's torture claim differently."). ${ }^{136}$ E.g. Zewdie v. Ashcroft, 381 F.3d 804, 808 n.4 (8th Cir. 2004) (nothing that “[ $t$ ]he immigration judge all but ignored the State Department's 
decisions in cases where the BIA did not adequately consider relevant information from State Department human rights reports.

This does not mean that the courts will automatically grant withholding of removal to anyone who comes from a country that practices torture. Showing that you are being deported to a country that tortures does not in itself prove that you personally are more likely than not to be tortured if deported. As the Seventh Circuit held in Rashiah v. Ashcroft,

Though the country report supports the contention that torture occurs in Sri Lanka, it does not demonstrate that it is more likely than not that petitioner will be tortured if he returns.... country report that describes instances of torture unrelated to the applicant does not provide a basis for withholding removal without evidence that the applicant himself will be targeted. ${ }^{137}$

Two factors are particularly important in Circuit Courts' evaluation of whether country

conditions show that the petitioner will be tortured if he or she is sent back: the applicant's membership in a group that the state has specifically targeted for torture, and the likelihood that the applicant will be imprisoned if returned.

In Tarrawally v. Ashcroft, the Third Circuit upheld the Immigration Judge's denial of CAT relief because the applicant failed to prove either of those things. ${ }^{138}$ The court explained that while the Country Reports showed evidence that citizens opposing Sierra Leone's ruling party "are specifically targeted for torture, including limb amputation," Tarrawally "has introduced no evidence other than his own testimony" that he belonged to any opposition group, and the Immigration Judge found his testimony not to be credible. ${ }^{139} \mathrm{He}$ also provided "no evidence...that the government detains individuals re-entering Sierra Leone"; therefore "the IJ did not err in

\footnotetext{
Report" and "[t]he BIA made no mention of the report").

137 Rashiah v. Ashcroft, 388 F.3d 1126, 1133 (7th Cir. 2004). See also Zubeda v. INS, 333 F. 3d 463 , 477 (3rd Cir. 2003) ("Of course, reports of generalized brutality within a country do not necessarily allow an alien to sustain his/her burden under the Convention Against Torture"); Ngure v. Ashcroft, 367 F.3d 975, 992 - 3 (8th Cir. 2004) (holding that State Department reports "are insufficient to demonstrate that it is more likely than not that a particular individual will be tortured by the government if returned....the State Department's report on the torture of a student leader also is not sufficient to compel reversal...because Ngure has not provided evidence that he is similarly situated").

138 Tarrawally v. Ashcroft, 338 F.3d 180, 187 - 9 (3rd Cir. 2003).

$139 \mathrm{Id}$. at 188 .
} 
refusing to grant relief." 140

In another Third Circuit case, Zubeda v. Ashcroft, the court vacated the BIA's decision denying relief in part because the BIA did not give enough weight to the Immigration Judge's finding that "I am convinced that [Zubeda] would be detained upon her arrival," which "greatly bolsters Zubeda's claim under the Convention given the apparent likelihood that she would be raped if detained." 141 Similarly, the Fourth Circuit overturned an Immigration Judge's decision in Camara v. Ashcroft because the judge failed to consider evidence of Guinea's "brutal repression" of the applicant's political party, and ignored "documentary evidence that she has escaped from prison and was now wanted by the police," including an outstanding arrest warrant. ${ }^{142}$

If these regulations and decisions are correct interpretations of the CAT -- and they seem to follow directly from the Article 3 requirement that "authorities shall take into account all relevant considerations" in evaluating the danger of torture -- then obtaining a diplomatic assurance that a prisoner will not be tortured after a rendition is not automatically sufficient for compliance. An unverified promise from Syria, Egypt, Jordan, Morocco or Uzbekistan that it will not torture a prisoner may be relevant to the likelihood of torture, but it cannot be the only relevant evidence. The country's record "of gross, flagrant or mass violations of human rights" 143 is also relevant, as is the fact that prisoners are sent directly into the custody of military intelligence for the purposes of detention and interrogation. U.S. officials are also obligated to consider the country's previous treatment of this detainee or other similarly situated detainees: other prisoners rendered by the United States or being interrogated at the request of the United States, other prisoners whom the government promised not to torture, other prisoners accused of involvement with Islamist terrorism, others being

\footnotetext{
140 Id. at 189.

141 Zubeda v. Ashcroft, 333 F.3d 463, 478 - 9 (3rd Cir. 2003).

142 Camara v. Ashcroft, 378 F. 3d 361, 372 (4th Cir. 2004).
} 
held at a particular prison, etc. They must decide based on all of this evidence whether a detainee is more likely than not to be tortured if he is rendered.

\section{B. "More Likely Than Not That He or She Would Be Tortured If Removed"}

The regulations state that "[t]he burden of the proof is on the applicant...to establish that it is more likely than not that he or she would be tortured if removed." 144 The courts take these words quite literally. As the Ninth Circuit stated in Hamoui v. Ashcroft, to get CAT relief, the applicant "has to show only a chance greater than fifty percent that he will be tortured if removed." 145 This is a purely objective test; "there is no subjective component for granting relief under the CAT." 146

The federal courts regard the BIA's final determination about whether an applicant is more likely than not to be tortured as a finding of fact. ${ }^{147}$ As such, it is "conclusive unless any reasonable adjudicator would be compelled to conclude to the contrary." 148 In contrast, the BIA's or immigration judge's decision to exclude or disregard relevant evidence about the possibility of torture is considered a legal error entitled to no deference. Because of the different standards of review, the courts are much less likely to overturn a BIA's decision because the Board evaluated the evidence badly than because the Board disregarded the statute's command to consider all relevant evidence. But it does happen. ${ }^{149}$

In cases where the courts have found that the evidence compelled the conclusion that a suspect was more likely than not to be tortured, three factors have been given special weight: evidence of past

\footnotetext{
143 8 C.F.R. $\$ 208.16(\mathrm{c})(3)(2004)$.

144 8 C.F.R. $\S 208.16(\mathrm{c})(2)(2004)$.

145 Hamoui v. Ashcroft, 389 F.3d 821, 827 (9th Cir. 2004). See also Khup v. Ashcroft, 376 F.3d 898, 907 (9th Cir. 2004) ("Khup faces at least a $51 \%$ chance of being tortured should he be removed to Burma.... We therefore hold that Khup is entitled to withholding of removal under Article 3 of the CAT").

146 Camara v. Ashcroft, 378 F.3d at 371.

147 See, e.g., Zewdie v. Ashcroft, 381 F.3d 804, 806 (8th Cir. 2004).

1488 U.S.C. $\$ 1252$ (b)(4)(B) (2004).

${ }^{149}$ E.g., Namo v. Gonzales, 401 F.3d 453 (6th Cir. 2005), Farah v. Ashcroft, 114 Fed. Appx. 325, 327 (9th Cir. 2005), Zewdie v. Ashcroft, 381
} 
torture and threats of future reprisal against the applicant; the likelihood that the applicant would be imprisoned upon his or her return; and a country's record of torturing similarly situated individuals. The first of these factors is not present in most cases of rendition, ${ }^{150}$ but the latter two are.

The prospect of imprisonment was an important factor in the 2005 case Namo v. Gonzales. The Sixth Circuit held that based on the applicant's credible testimony that "there was a warrant outstanding for his arrest in Iraq," combined with previous torture by government agents for failure to finish a construction project on schedule, "one must conclude that he met his burden" of proof under the Convention Against Torture. ${ }^{151}$

The torture, murder, or disappearance of the applicant's family members was central in three other cases. In Farah v. Ashcroft, the Ninth Circuit held that the applicant's membership of the Marchan clan in Somalia at a time when the Hawiye clan controlled the country and "the State Department Country Report supports the conclusion that a member of another clan would have 'a good chance of being subject to torture,"' combined with the applicant's testimony about his brother's murder and his sister's rape and murder by members of the Hawiye clan, "compels the conclusions that Farah will more likely than not be tortured in removed." ${ }^{152}$ In an earlier Ninth Circuit decision, Figueroa-Hincapie v. Fasano, the court held that the Colombian government's past imprisonment and torture of Figueroa's father for union organizing, the recent assassination of another labor activist's son in Figueroa's hometown, and Colombia's general patterns of human rights abuses formed a record that "compel[led] the conclusion" that Figueroa was more likely than not to be tortured. ${ }^{153}$ In Zewdie v. Ashcroft, evidence that the Ethiopian government had seized and detained Zewdie's husband after she fled the country, combined with physical evidence that she was been tortured by the government during a previous imprisonment and

F.3d at 810, Khup v. Ashcroft, 376 F.3d at 907, Figueroa-Hincapie v. Fasano, 86 Fed. Appx. 283, 286 (9th Cir. 2004). Some of these cases will be discussed in more detail infra.

150 But see the discussion of Mamdouh Habib in Section III(B)(1)(a), infra.

${ }^{151}$ Namo v. Gonzales, 401 F.3d 453 (6th Cir. 2005). Because of the possibility that the overthrow of Saddam Hussein's government reduced the risk of torture, the court remanded the case to the BIA rather than finding Namo eligible for withholding of removal.

152 Farah v. Ashcroft, 114 Fed. Appx. 325, 326 - 27 (9th Cir. 2004),

153 Figueroa-Hincapie v. Fasano, 86 Fed. Appx. 283, 286 (9th Cir. 2004). 
her testimony that the government had threatened her with reprisal if she returned, convinced the Eighth Circuit that "no reasonable fact finder could fail to find Zewdie eligible for relief."154

In the context of rendition, there no doubt at all that suspects will be detained and interrogated upon their arrival in the receiving state. There is not evidence about the torture or mistreatment of detainees' families, but there is a great deal of evidence of the treatment of similarly situated prisoners. The torture of suspects previously rendered to the same country after a diplomatic assurance not to torture is probably at least as strong a predictor of the danger of torture for the next suspect rendered there as the mistreatment of an asylum seeker's relatives. Evidence about the torture of other accused Islamic terrorists who were never in U.S. custody is also very relevant, as is the country's general record "gross, flagrant or mass violations of human rights."

Again, the Convention Against Torture and FARRA require the federal government to consider all of this information before deciding whether a prisoner is more likely than not to be tortured if removed.

\section{THE DANGER OF TORTURE AFTER RENDITION}

The next section will examine the "evidence relevant to the possibility of future torture" after a rendition. Subsections A and B will give a detailed history of the rendition program before and after September 11, respectively. Subsection C will summarize U.S. officials' statements about the reliability of diplomatic assurances and the likelihood of torture after rendition.

\section{A. HiSTORY OF RENDITION BEFORE SEPTEMBER 11}

The United States began rendering terrorism suspects to be interrogated in Middle Eastern

154 Zewdie v. Ashcroft, 381 F.3d 804, 808 - 10 (8th Cir. 2004). 
countries during Bill Clinton's presidency. ${ }^{155}$ According to Michael Scheuer, the former head of the CIA unit charged with dismantling al-Qaeda, by the mid-1990s the CIA had identified and located al-Qaeda leaders, but "we couldn't capture them because we had nowhere to take them." 156 Scheuer told BBC Radio that "basically, when CIA came back and said to the policymaker, where do you want to take them, the answer was -- that's your job."157 The CIA decided to send the suspects to third countries. In 1995, American intelligence proposed "rendering" suspects to Egypt, and Hosni Mubarak's government readily agreed. ${ }^{158}$ "What was clever was that some of the senior people in al-Qaeda were Egyptian," Scheuer explained to The New Yorker. "It served American purposes to get these people arrested, and Egyptian purposes to get these people back, where they could be interrogated."159

Scheuer stated that during the years when he was involved in renditions, "there was a legal process"160 approved by attorneys at the CIA, the National Security Council, and the Department of Justice. ${ }^{161}$ Every suspect had been convicted in absentia by a foreign government, ${ }^{162}$ and:

The idea that somehow this is a rogue operation that someone dreamed up is absurd...As I remember when I was the chief, after the lawyers have vetted the information and had said, 'Okay, you can do this legally,' I think it went to either the Director of Central Intelligence or to the Assistant Director of Central intelligence. So basically the number one and two men in the intelligence community are the ones who sign off. ${ }^{163}$

Scheuer continued, "I have never been involved in a case where I was not convinced, based on the intelligence, the information that was available, that these people deserved to be off the

\footnotetext{
155 Jane Mayer, Outsourcing Torture, THE NEW YORKER, Feb. 14, 2005, at 109, available at

http://www.newyorker.com/fact/content/2050214fa_fact6. More recent articles have stated that rendition was first used in the mid-1980s, but have given relatively few details about how it operated at that time. One article states that " $[t]$ ypically, they were used to bring people to the United States, not send them elsewhere. U.S. officials would snatch drug lords from countries that had not signed extradition treaties and then "arrest" them when the plane landed on U.S. soil," but it is possible that suspects were to third countries as well. Daniel Byman, Reject the Abuses, Retain the Tactic, WASH. POST, Apr. 17, 2005, at B1, available at http://www.washingtonpost.com/wp-dyn/articles/A58301 2005Apr16.html.

156 Jane Mayer, Outsourcing Torture, THE NEW YoRKER, Feb. 14, 2005, at 109.

157 File on Four: Rendition (BBC Radio 4 Broadcast, Feb. 8, 2005).

158 Jane Mayer, Outsourcing Torture, THE NEW YORKER, Feb. 14, 2005, at 109.

159 Id. at 109.

160 Id. at 110.

161 File on Four: Rendition (BBC Radio 4 Broadcast, Feb. 8, 2005).

162 Jane Mayer, Outsourcing Torture, THE NEW YORKER, Feb. 14, 2005, at 110.

163 File on Four: Rendition (BBC Radio 4 Broadcast, Feb. 8, 2005).
} 
street....Now, were mistakes made? Absolutely."164

The New Yorker has repored that the CIA remained in close contact with the Egyptian intelligence service after a rendition: "The partnership between the American and the Egyptian intelligence services was extraordinarily close: Americans could give the Egyptian interrogators questions they wanted put to the detainees in the morning, Scheuer said, and get answers by the evening." 165 However, Egypt refused to allow American agents to question suspects directly. ${ }^{166}$ The CIA sought diplomatic assurances that suspects would not be tortured before these transfers, but Scheuer has expressed doubts about their reliability. Asked whether detainees were tortured, Scheuer told BBC Radio, "It wouldn't be us torturing them."167

Former CIA Director George Tenet has testified that the agency had conducted over seventy renditions in the years before the attacks. ${ }^{168}$ These were not all "extraordinary renditions" in the sense this Article uses the term; approximately twenty were extrajudicial prisoner transfers to the United States. ${ }^{169}$

We know the names of nine of the suspects rendered before September 11. All were sent to Egypt.

1. Talaat Fouad Qassem (September 1995)

Talaat Fouad Qassem, an Egyptian Islamist who had been granted asylum in Denmark, was arrested in Zagreb, Croatia, in September 1995.170 U.S. officials questioned him for two days on a

164 Id.

165 Jane Mayer, Outsourcing Torture, THE NEw YORKER, Feb. 14, 2005, at 110.

166 Id.

167 File on Four: Rendition (BBC Radio 4 Broadcast, Feb. 8, 2005).

168 See, e.g., Douglas Jehl \& David Johnston, Rule Change Lets CIA Freely Send Suspects Abroad to Jails, N.Y. TIMES, Mar. 6, 2005 , at A1. 169 Id.

170 See Jane Mayer, Outsourcing Torture, THE NEW YorkER, Feb. 14, 2005, at 109; Anthony Shadid, America Prepares the War on Terror; U.S., Egypt Raids Caught Militants, Boston GloBe, Oct. 7, 2001. The Washington Post has reported that Qassem was sent to Egypt in 1998. Rajiv Chandrasekaran \& Peter Finn, U.S. Behind Secret Transfer of Terror Suspects, WASH. Post, Mar. 11, 2002, at A1. However, I believe this is erroneous, as the six other sources I have found say it was 1995. See Jane Mayer, Outsourcing Torture, THE NEW YoRKER, Feb. 14, 2005, at 109; Anthony Shadid, America Prepares the War on Terror; U.S., Egypt Raids Caught Militants, Boston GLOBE, Oct. 7, 2001; World Briefs 
ship in the Adriatic Sea, focusing on an alleged assassination plot against President Clinton by Egypt's Islamic Group, also known as Gamaa-el-Islamiya. ${ }^{171}$ On September 22, according to former Egyptian cleric and British asyleeYasser al-Sirri, the United States sent Qassem to Egypt. ${ }^{172}$

Egypt had previously imprisoned Qassem for seven years for a suspected role in the plot to assassinate Anwar Sadat. Qassem escaped in 1989. In 1992, an Egyptian military tribunal sentenced him to death in absentia, and pressured Pakistan to extradite him without success. ${ }^{173}$

Islamic militant sources in Egypt told a Boston Globe reporter that Egypt took Qassem to their intelligence headquarters in al-Mansoura, then moved him to Cairo in October $1995 .{ }^{174}$ On November 5, 1995, Gamaa-el-Islamiya alleged to United Press International that Qassem was "undergoing barbaric tortures" to gain intelligence. ${ }^{175}$ These charges were not independently verified, and Qassem has not been seen since. ${ }^{176}$ Egypt has refused to comment on his whereabouts or on whether he is dead or alive. ${ }^{177}$ Qassem's wife has said she believes he was executed several years ago, ${ }^{178}$ as has Egyptian journalist Hossam el-Hamalawy. ${ }^{179}$

\section{Ahmed Osman Saleh, Ahmed Ibrahim al-Naggar, Shawki Salama Attiya, Essam Abdel Tawwab, \& Muhammad Hassan Tita (July \& August 1998) \\ In 1998, the CIA arranged for Ahmed Osman Saleh, Ahmed Ibrahim al-Naggar, Shawki} Salama Attiya, Essam Abdel Tawwab, and Muhammad Hassan Tita to be sent to Egypt for

Column, Toronto Sun, Oct. 22, 1995, at 38; Egyptian Officers Killed; 21 Arrested, United Press InTERnational, Nov. 4, 1995; Wife of Egyptian Prominent Fundamentalist Ask Croatia to Reveal His Destiny, ARABICNEws.Com, Sept. 15, 2000, http://arabicnews.com/ansub/Daily/Day/000915/2000091502.html; Emad Mekay, Cry of a Beloved Wife, IsLAMONLINE.NET, Sept. 26, 2000, $\mathrm{http} / / /$ www.islamonline.net/iol-english/dowalia/news-2000-sep-26/topnews5.asp.

${ }_{171}$ Anthony Shadid, America Prepares the War on Terror; US, Egypt Raids Caught Militants, Boston Globe, Oct. 7, 2001.

172 Id.

${ }^{173} \mathrm{Id}$. This is in contrast to many later cases of rendition, where Egypt, Jordan or Syria only charged the suspect at the United States' request.

174 Id.

175 Egyptian Officers Killed; 21 Arrested, United PreSs InTERNATIONAL, Nov. 4, 1995.

176 Jane Mayer, Outsourcing Torture, THE NEW YORKER, Feb. 14, 2005, at 109.

177 Rajiv Chandrasekaran \& Peter Finn, U.S. Behind Secret Transfer of Terror Suspects, WASH. Post, Mar. 11, 2002 , at A1.

178 Anthony Shadid, America Prepares the War on Terror; US, Egypt Raids Caught Militants, Boston GLOBE, Oct. 7, 2001.

179 Jane Mayer, Outsourcing Torture, THE NEW YORKER, Feb. 14, 2005, at 109. 
interrogation and imprisonment. According to the Wall Street Journal, they were all members of an Islamic Jihad cell in Tirana, Albania that U.S. officials considered "among the most dangerous terror outfits in Europe." 180

The CIA had been aiding Albania's intelligence service in conducting surveillance on the suspects since the early 1990s. ${ }^{181}$ In 1998, with U.S. considering military action in nearby Kosovo, Ahmed al-Naggar and Shawki Attiya began making frequent phone calls to Islamic Jihad leader Ayman al-Zawahiri. ${ }^{182}$ At the time, Islamic Jihad was merging with al-Qaeda and shifting its focus from attacks on the Egyptian government to attacks on American targets. ${ }^{183}$ In the spring of 1998, the CIA asked Albania to help round up six local suspects. According to Albanian intelligence officials, the CIA sent approximately twelve agents to coordinate the arrests. ${ }^{184}$ The U.S. and Albania spent three months planning the operation; Egypt issued pre-arranged charges and extradition requests against some of the suspects during this time. ${ }^{185}$

Shawki Attiya was arrested on June 26, 1998, and flown to Cairo on a CIA-chartered private jet on July 2. ${ }^{186}$ Ahmed al-Naggar was also arrested and flown to Cairo in early July. ${ }^{187}$ Muhammad Hassan Tita was sent to Egypt about two weeks later. ${ }^{188}$ In August, Ahmed Osman Saleh was arrested in Tirana and Essam Abdel Tawwab was arrested in Sofia, Bulgaria. ${ }^{189}$ All five men were turned over to Egyptian intelligence as soon as they arrived in Cairo, and tried with dozens of other suspects before a military tribunal in a trial that became known as the

\footnotetext{
${ }^{180}$ Andrew Higgins \& Christopher Cooper, Cloak and Dagger: A CIA-Backed Team Used Brutal Means to Crack Terror Cell, WALL ST. JouRNAL, Nov..20, 2001, at A1.

181 Id.

182 Id.

$183 \mathrm{Id}$.

${ }^{184} \mathrm{Id}$.

185 Id.

${ }^{186} \mathrm{Id}$.

187 Id.

188 Id.

189 Id. See also Richard Sale, Renditions Pro and Con, United Press InTERnational, Jan. 20, 2005.
} 
"Returnees from Albania" case. All five alleged that they were tortured in Egyptian custody.

The Egyptian Organization for Human Rights ("EOHR") sent an observer to the trial, and

recorded the following allegations of torture from the evidence presented by the prosecution and

defense. ${ }^{190}$ (I have not attempted to correct errors in spelling, translation or grammar.)

Shawki Salama Attiya, called Shawki Salama Mustafa in EOHR documents,

said in his testimony before the State Security Prosecution that he was detained for 65 days, the water covered his knee and he was tortured as follows: - His legs were tied and he was dragged on his face. - He was tortured also in the State Security Investigation as he was tied, his legs and hands was tied, his legs and hands was suspended and they passing electricity to his male organ and castrates ${ }^{191}$ and they even threatened of sexually abusing him. ${ }^{192}$

Essam Abdel Tawwab, called Essam Abdel Tawab Abdel Aleim in EOHR documents,

said in his testimony before the State Security Prosecution that he was tortured in the State Security prosecution as follows: - He was beaten by hands and legs. - He was assaulted by a sharp tool which resulted in a wound cut by the right hands. - His hands and feet were tied and he was hanged. - Electricity was connected to sensitive parts in his body. ${ }^{193}$

Naggar, called Ahmed Ibrahim El Sayed El Nagar in EOHR documents,

said in his testimony before the State Security Prosecution that he was detained in an unknown place for 35 daysas he stated to the EOHR lawyers. During this period he was blindfolded and was lodging for 24 hours in a room covered with water to reach his knees and then he was moved to State Security investigation and he was tortured as follows: - His legs and his hands were tied behind his back. He was forced to lie on a sponge mattress and a chair was put on his chest and another between his leg. Electricity was passed to his body and he was forced to make confessions during torture. ${ }^{194}$

Muhammad Hassan Tita stated in his written confession that "[a]fter I was arrested, [Egyptian interrogators] hung me from my wrists and applied electricity to parts of my feet and back. ${ }^{195}$ Ahmed Osman Saleh told his lawyer, Hafez Abu Seada of EOHR, that he was tortured with electrical shocks and by being suspended from the ceiling of his cell. ${ }^{196}$

Ahmed Naggar's brother Muhammad told the Wall Street Journal that he and several of his other relatives had been tortured by Egyptian police, ${ }^{197}$ and "said he had suffered broken ribs and

\footnotetext{
190 Egyptian Organization FOR Human Rights, Victims Without Rights: THE EOHR's Report On TORTuRE In POLICE STATIONS AND DETENTION CENTERS IN EGYPT, Section $2 \mathrm{~b}$ (Apr. 3, 2002), at http://www.eohr.org/report/2002/dahaya2-b.htm.

191 It appears from the context that this is a mistranslation of "testicles."

192 Id.

193 Id.

${ }^{194} I d$.

195 Id.

196 Id.

197 Andrew Higgins \& Christopher Cooper, Cloak and Dagger: A CIA-Backed Team Used Brutal Means to Crack Terror Cell, WALL ST.
} 
fractured cheekbones." 198

Naggar and Saleh had already been convicted in absentia on other terrorism charges and sentenced to death. ${ }^{199}$ They were hanged in February 2000. ${ }^{200}$ Attiya was sentenced to life imprisonment, and Tita and Tawwab were sentenced to ten years in prison. ${ }^{201}$

\section{Ahmed Salama Mabrouk, Essam Hafez, \&} Ihab Muhammad Saqr (July or September 1998)

The United States helped arrange the transfer of Ahmed Salama Mabrouk and Essam Hafez from Azerbaijan to Egypt in 1998. Mabrouk and Hafez, allegedly close associates of Ayman alZawahiri, were defendants in the same Egyptian mass trial as Attiya, Naggar, Saleh, Tawwab and Tita. A Egyptian newspaper description of the trial in March of 1999 states that Ahmed Salama Mabrouk "shouted from his cage that he was arrested in September in the course of a business trip in Azerbaijan...Mabrouk, like the other defendants, alleged that he had been tortured." 202 The same article reports that Hafez "said he was also arrested in September in Azerbaijan in the course of a business trip." 203

A U.S. intelligence research group reported in April 1999 that the leader of London's Islamic Observation Center, Yasir al-Sirri, "affirmed that it was U.S. intelligence that apprehended" Hafez and Mabrouk in Baku, Azerbaijan and handed them over to Egypt. ${ }^{204}$ The same article reported that before being sentenced to hard labor for life by Egypt, Mabrouk had boasted of a plan against attacks on U.S. targets that he said "was on a computer disk confiscated from him 
during his arrest by the U.S. Central Intelligence Agency in Azerbaijan." ${ }^{205}$ More recently, The New

Yorker also reported that the CIA arrested Mabrouk and another Islamic Jihad member in Baku, and that Mabrouk's "laptop computer turned out to contain vital information" about the terror network, but gave the date of the arrest as July 1998. ${ }^{206}$

A third suspect, Ihab Saqr was also transferred from Azerbaijan to Egypt in 1998.207 Some sources say he was arrested at the same time as Mabrouk and Hafez, ${ }^{208}$ but other descriptions of Mabrouk's and Hafez' arrests make no mention of Saqr. ${ }^{209}$ This may only be because Saqr was tried separately, several months after the "Returnees from Albania" case,${ }^{210}$ or it may be that the arrests were actually separate incidents.

Hafez and Mabrouk were found guilty and sentenced to life imprisonment with hard labor. ${ }^{211}$ I could not find any reports on the outcome of Saqr's trial.

The allegations of torture after these renditions are consistent with the State Department's 1995 - 2001 Country Reports on Human Rights Practices for Egypt, which all alleged widespread and severe torture of prisoners, sometimes ending in death. ${ }^{212}$ According to the 2001 report, for example,

Principal methods of torture employed by the police, as reported by victims, included: Being stripped and blindfolded; suspended from a ceiling or doorframe with feet just touching the floor; beaten with fists, whips, metal rods, or other objects; subjected to electrical shocks; and doused with cold water. Victims frequently report being subjected to threats and forced to sign blank papers to be used against the victim or the victim's family in the future should the victim complain of abuse. Some victims, including male and female detainees, reported that they were sexually assaulted or threatened with the rape of themselves or family members....

205 Id.

206 Lawrence Wright, The Man Behind Bin Laden, THE NEW YORKER, Sept. 16, 2002.

207 Egyptian State Security Prosecution Investigates Fundamentalist Delivered by Azerbaijan, ARABICNEWS.COM, May 29, 1999, at http://www.arabicnews.com/ansub/Daily/Day/990529/1999052922.html.

208 E.g. id.

209 E.g., Lawrence Wright, The Man Behind Bin Laden, THE NEW YORKER, Sept. 16, 2002.

210 Jailan Halawi, Pre-Emptive Strike Against Jihad, AL-AHRAM WEEKLY, June 3, 1999.

211 Steve Macko, Counterterrorism Analysts Take Note of New Threats From Egyptian Terrorist Group, ERRI DAILY INTELLIGENCE REPORT, Apr. 20, 1999, http://www.emergency.com/1999/ejihad99.htm.

212 U.S. DEPARTMENT OF STATE, COUNTRY REPORTS ON HUMAN RIGHTS PRACTICES: EGYPT -- 2001 (Mar. 2002 ); U.S. DEPARTMENT OF State, Country Reports on Human Rights Practices: EGyPT -- 2000 (Feb. 2001); U.S. DePARTMSENT OF STATE, Country RePORTS ON Human Rights Practices: Egypt -- 1999 (Feb. 2000); U.S. DEPARTMENT OF State, Country RePORTS ON HuMAN Rights Practices: EGYPT -- 1998 (Feb. 1999); U.S. DEPARTMENT OF STATE, COUNTRY REPORTS ON HuMAN Rights PRACTICES: EGYPT -- 1997 (Jan. 1998 ); U.S. Department of State, Country Reports on Human Rights Practices: Egypt -- 1996 (Jan. 1997); U.S. Department of State, COUNTRY REPORTS ON HuMAN RIGHTS PRACTICES: EGYPT -- 1995 (Mar. 1996). All of the State Department's Country Reports from 1993 2004 are available at http://www.state.gov/g/drl/hr/c1470.htm. 
Human rights organizations and the press reported on the death in custody of four persons, reportedly under police torture, during the year. ${ }^{213}$

Moreover, as noted above, the Washington Post has reported that "after years of fruitless talks in Egypt" about the torture of suspects, President Bill Clinton cut off funding and cooperation with the directorate of Egypt's general intelligence service."214 This indicates that the Clinton administration knew that suspects rendered to Egypt were being tortured despite diplomatic assurances.

\section{B. History OF RENDITION SINCE SEPTEMBER 11}

After September 11, the rendition program expanded, and began operating under fewer legal restrictions. Anonymous "current and former government officials" told the New York Times that several days after the attacks on the World Trade Center and the Pentagon, President Bush signed a classified order that allowed the CIA to carry out renditions without White House, Department of State, or Department of Justice approval of individual prisoners' transfers. ${ }^{215}$ The CIA was also authorized to transfer prisoners to countries where they did not face any criminal charges, "solely for the purpose of detention and interrogation." 216 United Press International reported that the document was called a "memorandum of notification," and was signed on September $17,2001 .^{217}$

The number of renditions since September 11 has been estimated at "100 to $150 " 218$ and “150 to $200 . " 219$

The following are the specific cases of rendition since September 11 that are publicly known. To simplify the legal analysis in Section IV, they are arranged by country.

\footnotetext{
213 U.S. Department of State, Country Reports on Human Rights Practices: Egypt -- 2001 (Mar. 2002), http://www.state.gov/g/drl/rls/hrrpt/2001/nea/8248.htm.

${ }^{214}$ Dana Priest \& Barton Gellman, U.S. Decries Abuse But Defends Interrogations, WASH. Post, Dec. 26, 2002, at A1, available at http://www.washingtonpost.com/ac2/wp-dyn/A37943 - 2002Dec25?language=printer.

215 Douglas Jehl \& David Johnston, Rule Change Lets CIA Freely Send Suspects Abroad to Jails, N.Y. TiMES, Mar. 6, 2005.

$216 \mathrm{Id}$.

217 Shaun Waterman, Ex-CIA Lawyer Calls for Law on Rendition, UNITED PRESS INTERNATIONAL, Mar. 8, 2005.

218 Douglas Jehl \& David Johnston, Rule Change Lets CIA Freely Send Suspects Abroad to Jails, N.Y. TIMES, Mar. 6, 2005.

219 Michael Gaswenda, U.S. Defends "Rendition" of Terror Suspects, THE AgE (Australia), Mar. 9, 2005.
} 


\section{Renditions to Egypt}

Egypt's human rights record has not improved since September 11. The Statement

Department's 2001, 2002, 2003 and 2004 human rights reports all discuss widespread and severe torture in Egyptian prisons. ${ }^{220}$ The 2004 report cited a study by the Egyptian Organization for Human Rights that

documented 41 cases of torture in police stations resulting in 15 deaths in custody from April 2003 to April 2004. EOHR also asserted that from April 1993 to April 2004, it documented 412 cases of torture in police stations, including 120 cases where detainees died as a direct result of torture. ${ }^{221}$

The known cases of rendition to Egypt since September 11 are listed below. For discussion of

Egypt's alleged torture of Ahmad el-Maati, see Section I.

a. Mamdouh Habib (October 2001)

In early October 2001, Australian citizen Mamdouh Habib was arrested in Pakistan, where he has been accused of attending Lashkar-e-Taiba and al-Qaeda training camps ${ }^{222}$ and of fighting against U.S. forces. ${ }^{223}$ Habib has made the following allegations about his subsequent treatment, as reported through his attorney in an application for a temporary restraining order:224

Habib was held for three weeks in several different Pakistani prisons. ${ }^{225}$ In one prison, he was interrogated by three intelligence agents, one man and two women, who spoke English with American accents. ${ }^{226} \mathrm{He}$ was eventually taken to an airfield near Islamabad, where "he struggled

\footnotetext{
${ }^{220}$ U.S. Department of State, Country Reports on Human Rights Practices: Egypt -- 2004 (Feb. 2005); U.S. DePartment OF State,

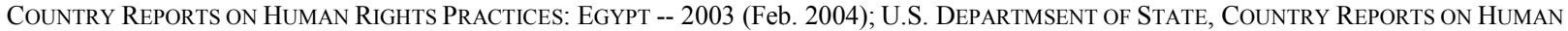
Rights Practices: EgYPT -- 2002 (Mar. 2003); U.S. DePARTMENT OF StATE, COUNTRY REPORTS ON HuMAN Rights PRACTICES: EGYPT -2001 (Mar. 2002). All of the State Department's Country Reports from 1993 - 2004 are available at http://www.state.gov/g/drl/hr/c1470.htm.

221 U.S. Department of State, COuntry Reports on Human Rights Practices: Egypt -- 2004 (Feb. 2005).

222 Martin Chulov, Habib “In Terror Camp” on 9/11, ThE Australian, Feb. 5, 2005.

223 Jane Mayer, Outsourcing Torture, THE NEW YORKER, Feb. 14, 2005, at 118.

224 See generally Declaration of Joseph Margulies, attached to Plaintiff's Application for Temporary Restraining Order, Habib v. Bush, filed November 24, 2004. (D .C. Dist.) (No. 02-CV-1130) [hereinafter "Margulies Declaration"]. Habib was being held incommunicado at Guantanamo Bay at the time for security reasons, so his attorney reported his factual allegations to the court.

225 Id. at 95.

226 Id. at 5.
} 
and was forcibly subdued by several" Americans. ${ }^{227}$ All spoke English with an American accent, and one had an American flag tattooed near his wrist. ${ }^{228}$ After they restrained and handcuffed Habib, one "placed his foot on Mr. Habib's neck and posed while another took pictures."229 Habib's clothes were cut away with scissors. ${ }^{230}$ He was dressed in a "blue track suit" and transferred to a plane, which flew him to Cairo. ${ }^{231}$

Makhdoom Syed Faisal Saleh Hayat, Pakistan's Interior Minister, later told the Australian television show Dateline that Habib was sent to Egypt on U.S. orders and in U.S. custody: "The US wanted him for their own investigations. We are not concerned where they take him," Hayat said. ${ }^{232} \mathrm{He}$ also stated that Egypt had not requested Habib's extradition. ${ }^{233}$

Habib told his lawyer that he was imprisoned in Egypt for six months, in a windowless six by eight foot cell, and that he was routinely and brutally tortured during his interrogation sessions: ${ }^{234}$

Mr. Habib, handcuffed and sometimes suspended from hooks on the wall, was kicked, punched, beaten with a stick, and rammed with what can only be described as an electric cattle prod. If he lapsed into unconsciousness they would revive him and continue the beatings. ${ }^{235}$

Habib described being held in three different water-filled rooms. ${ }^{236}$ In one the water level rose gradually, until it was just below his chin if he stood on his toes; he remained this way for several hours. In another, the water only reached his knees, but the room's ceiling was too low to stand and guards would not allow him to sit or kneel.237 In a third, where the water rose to his ankles, guards showed him a large electric switch in the next room and told he would be electrocuted if he did not

\footnotetext{
227 Id. at 6.

228 Id. at 96.

229 Id. at 97.

230 Id. at 98.

231 Id. at 98 - 9.

232 Dateline: The Trials of Mamdouh Habib (SBS television broadcast, July 7, 2004.)

233 Id.

234 Margulies Declaration at 99 - 10.

235 Id. at 910

236 Id. at 911 .

${ }^{237}$ Id. at 11 . This recalls the allegations of Ahmed Ibrahim El-Naggar and Shawki Attiya, supra.
} 
confess. ${ }^{238}$ Habib also described being tortured with electric shocks until he fainted, and being threatened with sexual assault by a trained German Shepard dog. ${ }^{239}$

There is some corroboration for these allegations. Dr. Hajib al-Naumi, Qatar's former justice minister, told Dateline that according to reports from contacts of his in Egypt, Habib "was in fact tortured. He was interrogated in a way which a human cannot stand up...We were told that he -they rang the bell that he will die and somebody had to help him."240

In the spring of 2002, Habib was transferred from Egypt to Bagram Air Force Base in Afghanistan, and then to the U.S. detention facility in Guantánamo Bay. ${ }^{241}$ Ian Kemish, a spokesman for Australia's Foreign Affairs Department, told Dateline that ten days after he arrived in Guantánamo, Habib "made some serious complaints about maltreatment during his time in Egypt" to visiting Australian officials. ${ }^{242}$

Several prisoners who have been released from Guantánamo have described encountering Habib there. In July 2004, three British detainees, Shafiq Rasul, Asif Iqbal, and Rhuhel Ahmed, gave a detailed public statement that made the following allegations about Habib's condition:

[Mamdouh] Habib himself was in catastrophic shape - mental and physical. As a result of his having been tortured in Egypt he used to bleed from his nose, mouth and ears when he was asleep. We would say he was about 40 years of age. He got no medical attention for this. We used to hear him ask but his interrogator said that he shouldn't have any. The medics would come and see him and then after he'd asked for medical help they would come back and say if you cooperate with your interrogators then we can do something. ${ }^{243}$

Jamal al-Hirith, an English detainee who was returned to Manchester in March, 2003, also has

described Habib bleeding from his nose and ears. ${ }^{244}$ Harith recently told The New Yorker that Habib

said that he had been in Egypt for about six months, and they had injected him with drugs, and hung him from the

238 Id. at 11.

${ }^{239}$ Id. at 12 - 13. According to The New Yorker, "Hossam el Hamalawy said that Egyptian security forces train German sheperds for police work, and that other prisoners have also been threatened with rape by trained dogs, although he knows of no one who has been assaulted this way." Jane Mayer, Outsourcing Torture, THE NEW YORKER, Feb. 14, 2005, at 118.

240 Dateline: The Trials of Mamdouh Habib (SBS television broadcast, July 7, 2004).

241 Margulies Declaration at 914.

242 Dateline: The Trials of Mamdouh Habib (SBS television broadcast, July 7, 2004).

243 Shafiq Rasul, Asif Iqbal \& Rhuhel Ahmed. Composite Statement: Detention in Afghanistan and Guantanamo Bay 122 (July 26, 2004) (available at http://www.ccr-ny.org/v2/legal/Sept._11th/docs/Guantanamo_composite_statement_FINAL.pdf).

244 Kate Gauntlett, Another Detainee Says Habib Tortured, THE WEST AUSTRALIAN, May 22, 2004, at 9. (“"Blood was coming out of his nose and out of his ears,' Mr al-Harith told the Seven Network in London.") 
ceiling, and beaten him very, very badly. He seemed to be in pain. He was haggard-looking. I never saw him walk. He always had to be held up. ${ }^{245}$

Former detainee Tarek Dergoul, also from England, described Habib to Dateline as

Very confused, dizzy. Dazed. Weak. Slow - he spoke very slow - he spoke in riddles. I couldn't really make out, I mean, like he was telling me stuff about Egypt, he'd been taken to Egypt...He told me he'd been electrocuted, put in water, electrocuted, he'd been stripped, been punched, kicked and punched, used as a punching bag. He said something about a dog being put on him as he was naked. Cigars put out on his body. Blindfolded. ${ }^{246}$

On November 18, 2004, Habib's lawyer Joseph Margulies read a news report that Egypt was negotiating with the United States for the return of five prisoners from Guantánamo Bay to Egypt, including Habib. ${ }^{247}$ On November 24, Margulies applied for a temporary restraining order preventing his client's transfer to Egypt. ${ }^{248}$ U.S. District Judge Joyce Hens Green denied this application without prejudice on November 29, apparently based on the government's reassurances that they were not currently planning to send Habib to Egypt, but ordered the government to provide at least five days advance notice before any transfer. ${ }^{249}$ In early January, 2005 John Altenburg of the U.S. Office of Military Commissions ruled that there was insufficient evidence for Habib's case to go before a commission. ${ }^{250}$ On January 28 Habib was sent from Guantánamo to Sydney, Australia, where he has not been charged with a crime but remains under surveillance. ${ }^{251}$

b. Ahmed Agiza \& Muhammad al-Zery (December 2001)

On December 18, 2001, the United States transported Swedish asylum seekers Ahmed Agiza and Muhammad al-Zery from Stockholm's Bromma airport to Cairo. Paul Forell, a police officer stationed at the airport that night, gave a very detailed account of the rendition to the Swedish

\footnotetext{
245 Jane Mayer, Outsourcing Torture, THE NEW YoRKER, Feb. 14, 2005, at 118.

246 Dateline: The Trials of Mamdouh Habib (SBS television broadcast, July 7, 2004).

247 Margulies Declaration at $9 \uparrow 2,3$.

248 Plaintiff's Application for Temporary Restraining Order, Habib v. Bush, filed Nov. 24, 2004. (D .C. Dist.) (No. 02-CV-1130).

249 See Order Denying Without Prejudice Application for Temporary Restraining Order, Habib v. Bush, ordered Nov. 29, 2004. (D.C. Dist.) (No. 02-CV-1130).

250 Roy Eccleston, U.S. Had "Plenty of Time" for Habib Case, The Australian, Feb. 2, 2005, available at http://www.news.com.au/story/0,10117,12170146 - 2,00.html

251 Raymond Bonner, Australian's Long Path in U.S. Antiterrorism Maze, N.Y. TIMES, Jan. 29, 2005.
} 
television show "Kalla Fakta."252

Forell said he waited with the Swedish security police and two Americans in civilian clothing for the prisoners. ${ }^{253}$ The suspects arrived after twenty minutes. They were handcuffed, footcuffed and blindfolded, and were each escorted by three or four American agents, who were also wearing hoods or balaclavas. ${ }^{254}$ Forell stated that one of the masked American agents was giving orders. ${ }^{255}$

Forell escorted the suspects into a small room and waited outside. ${ }^{256}$ An anonymous source told Kalla Fakta that in the changing room, Agiza and al-Zery's clothes were cut off. ${ }^{257}$ They were given rectal suppositories, which the witness believed contained sedatives, and dressed in dark overalls. ${ }^{258}$ "When they left the changing-room, they had their clothes changed into overalls, and were still with handcuffs and footcuffs. They were taken out to the cars, and then away," Forell said. ${ }^{259}$

According to the Washington Post, declassified Swedish government documents summarizing the case "noted that "the American side"" had offered to assist in the deportation "by lending a plane for the transport," and that "the transport from Sweden to Egypt was carried out with the help of American authorities." 260 Swedish diplomats wrote in a confidential memo that their government agreed to the deportation only after Egypt gave assurances that Agiza and AlZery would "not be subjected to inhuman treatment or punishment of any kind."261

Airport records show that a Gulfstream V jet identified by the Federal Aviation Administration ("FAA") registration number N379P flew from the Swedish airport to Cairo that

\footnotetext{
252 Kalla Fakta: The Broken Promise, Part II (television broadcast on Sweden's TV4, May 24, 2004, English transcript available at http://www.hrw.org/english/docs/2004/05/24/sweden9219.htm).

$253 \mathrm{Id}$.

254 Id.

255 Id.

256 Id.

257 Id.

258 Id.

259 Id.

260 Craig Whitlock, A Secret Deportation of Terror Suspects, WASH. Post, July 25, 2004, at A1.

${ }^{261}$ Id.
} 
night. ${ }^{262}$ Agiza and al-Zery were held in the Masra Tora prison, which is just south of Cairo. ${ }^{263}$

Agiza's mother Hamida Shalaby says they were tortured there. She told Kalla Fakta,

The mattress had electricity. The mattress. He would lay on it - like this - and his arms in chains on both sides and his legs in chains too. When they connected to the electricity, his body would rise up and then fall down and this up and down would go on until they unplugged electricity. ${ }^{264}$

Shalaby said this happened four times from December 19 to February 20, and "every day"

Agiza was tortured with electrodes while strapped to a chair. ${ }^{265}$

Hamida Shalaby and Agiza's father made similar but more detailed allegations about Agiza's treatment in submissions to the United Nations Committee Against Torture in a suit brought by

Agiza's wife. ${ }^{266}$ The submissions, as summarized by the Committee, alleged that on a January 23 ,

2002 visit to Masra Tora prison, Agiza

seemed pale, weak, seemingly in shock and near breakdown. His eyes, cheeks and feet were allegedly swollen, with his nose larger than usual and bloodied. He told that he had been tied and hung upside down while transported to the prison, and then being constantly blindfolded and subjected to advanced methods of interrogation, including electric shocks. ${ }^{267}$

On April 16, 2002,

He allegedly whispered to his mother that he had been further tortured by electric shocks after the January visit, and held in solitary confinement for about ten days. His arms and legs were tied behind his back and he could not relieve himself. He said he had told the Swedish Ambassador about the torture, and that prison officers had urged him to decline further visits from the Ambassador. He stated that officers had told him his wife would be returned soon, and they threatened to assault her and his mother sexually. He said he remained in solitary confinement, in a cell measuring two square meters, without windows, heat or light and that, while not tied, he could only visit the toilet once every 24 hours, which caused him kidney problems. ${ }^{268}$

Swedish government documents corroborate some of these allegations. Sven Linder,

Sweden's ambassador to Egypt, wrote a public report of a visit with the prisoners stating that Agiza and al-Zery said they were treated "excellently" and "seemed well-nourished and show no external signs of physical abuse." 269 However, a classified section of the same report noted that Agiza had complained

\footnotetext{
262 Kalla Fakta: The Broken Promise, Part I (television broadcast on Sweden's TV4, May 17, 2004.)

263 Id

264 Id. This is very similar to Ahmed Ibrahim al Naggar's allegations of torture in Egypt, supra.

265 Id.

266 Attia v. Sweden, CAT/C/31/D/199/2002, Nov.24, 2003,

http://www.unhchr.ch/tbs/doc.nsf/MasterFrameView/419f36fabc1ba168c1256df2002cb2f8?Opendocument.

267 Attia v. Sweden at 7 7.1.

268 Attia v. Sweden at 97.2

269 Craig Whitlock, A Secret Deportation of Terror Suspects, WASH. Post, July 25, 2004, at A1..
} 
of repeated beatings in prison. ${ }^{270}$

Al-Zery was released from prison in October of 2003, but as of last July he had not been permitted to leave the country and was being kept under surveillance by Egyptian intelligence. ${ }^{271}$ He canceled an interview with the Washington Post on the orders of an Egyptian security official. $^{272}$ In an interview with Kalla Fakta conducted under the supervision of Egyptian security officers, al-Zery denied that he had been tortured. ${ }^{273}$ But al-Zery's lawyer, Kjell Jonsson, told the Swedish program that

it's evident that he is speaking under coercion. . This information, that they have been tortured is now confirmed. It is about very painful torture. They fasten electrodes to the most sensitive parts of the body. That is, genitals, breast nipples, tongue, ear lobes, underarms. There are physicians present to judge how much torture, how much electricity, the prisoners can take. Afterwards the exposed parts are anointed, so that there won't be marks and scars, and cold water is poured to stop blood clots. ${ }^{274}$

Agiza had been convicted in absentia by a military court in the "Returnees from Albania" case, and sentenced to life imprisonment with hard labor. ${ }^{275}$ In February 2004 Agiza's attorney, Hafez Abu Seada of EOHR, requested a retrial on the grounds that his client had been unable to defend himself and was convicted largely on the testimony of one unreliable witness. ${ }^{276}$ In April 2004, Hosni Mubarak overturned the sentence and ordered a retrial by another military tribunal, which quickly reached the same verdict and sentence. ${ }^{277}$ Later that year Abu Seada alleged in a speech that "Agiza was tortured during his detention in state security investigations headquarters and Tora Prison and kept blindfolded for a month...He was kept in solitary detention for 46 days in punishment for complaining about having been tortured." 278

270 Id.

271 Id..

272 Id.

273 Kalla Fakta: The Broken Promise, Part I (television broadcast on Sweden's TV 4, May 17, 2004).

274 Id. Hamina Shalaby also described an ointment being used to prevent visible scars from forming after electrical torture. See Craig Whitlock, A Secret Deportation of Terror Suspects, WASH. POST, July 25, 2004, at A1.

275 Hafez Abu Seada, Speech at the International Commission of Jurists (ICJ) Biennial Conference in Berlin (Aug. 27, 2004) (transcript available at http://www.eohr.org/report/2004/re10.htm).

276 Id.

277 Id.

278 Id. 
In May 2005, the United Nations Committee Against Torture found that Sweden's

cooperation with Agiza's rendition violated Article 3 of the CAT, and that "[t]he procurement of diplomatic assurances, which, moreover, provided no mechanism for their enforcement, did not suffice to protect against" the "manifest risk" of torture. ${ }^{279}$

c. Ibn al-Sheikh al-Libi (late 2001 or early 2002)

Ibn al-Sheikh al-Libi, who ran al-Qaeda's terrorist training camp in Khalden, Afghanistan, ${ }^{280}$

was captured by Pakistani forces several months after September 11 and turned over to the United States for interrogation. ${ }^{281}$ There was a disagreement between the FBI and CIA about how to interrogate al-Libi. FBI agent Jack Cloonan told The New Yorker that he advised agents in Afghanistan to "handle this like it was being done right here, in my office in New York." 282 FBI agents read al-Libi his rights, and an FBI interrogator told Newsweek, "he was basically cooperating with us," ${ }^{283}$ But the CIA believed al-Libi was lying, ${ }^{284}$ and:

[t]he CIA station chief in Afghanistan, meanwhile, appealed to the agency's hawkish counterterrorism chief, Cofer Black. He in turn called CIA Director George Tenet, who went to the White House. Al-Libi was handed over to the CIA. "They duct-taped his mouth, cinched him up and sent him to Cairo" for more-fearsome Egyptian interrogations, says the ex-FBI official. "At the airport the CIA case officer goes up to him and says, 'You're going to Cairo, you know. Before you get there I'm going to find your mother and I'm going to f--- her.' So we lost that fight." 285

Newsweek has reported that al-Libi was "a crucial source" for the Bush administration's

allegations, in the months before the war in Iraq, that Saddam Hussein's regime had provided al-Qaeda with chemical weapons training. ${ }^{286}$ After the war, when interrogators revisited the subject with al-

\footnotetext{
279 Agiza v. Sweden, Communication No. 233/2003, U.N. Doc. CAT/C/34/D/233/2003 (2005), available at

http://www1.umn.edu/humanrts/cat/decisions/233 - 2003.html.

280 Jane Mayer, Outsourcing Torture, THE NEW YORKER, Feb. 14, 2005, at 114.

281 Odyssey into the Shadows, NEWSWEEK, June 24, 2002.

282 Jane Mayer, Outsourcing Torture, THE NEW YORKER, Feb. 14, 2005, at 114.

283 Michael Hirsh, John Barry, \& Daniel Klaidman, A Tortured Debate, NEwswEEK, June 21, 2004, at 50.

284 Jane Mayer, Outsourcing Torture, THE NEW YORKER, Feb. 14, 2005, at 116.

285 Michael Hirsh, John Barry, \& Daniel Klaidman, A Tortured Debate, NEwsweEK, June 21, 2004 , at 50.

286 Michael Isikoff, Periscope: Terror: Swapping Stories, NewsweEK, July 25, 2004. Colin Powell stated in his February 2003 speech before the United Nations Security Council that source of the information about chemical weapons training was "a senior terrorist operative...responsible for one of Al Qaeda's training camps in Afghanistan.” Jane Mayer, Outsourcing Torture, THE NEW YoRKER, Feb. 14, 2005 , at 116 .
} 
Libi, he “" 'recounted a different story,' said one U.S. official. Some officials now suspect that alLibi, facing aggressive interrogation techniques, had previously said what U.S. officials wanted to hear." ${ }^{287}$ FBI agent Dan Coleman told The New Yorker "[i]t was ridiculous for interrogators to think Libi would have known anything about Iraq. I could have told them that... The reason they got bad information is that they beat it out of him." 288

Al-Libi was later transferred to Guantánamo Bay. ${ }^{289}$

d. Muhammad Saad Iqbal Madni (January 2002)

Muhammad Saad Iqbal Madni, a Pakistani national, was arrested in Jakarta, Indonesia on January 9, 2002.290 Indonesian officials and diplomats told the Washington Post that this happened at the CIA's request. ${ }^{291}$ A few days earlier, the CIA had told Indonesian intelligence that Madni was an al-Qaeda member who had worked with the "shoe bomber" Richard Reid, gave information about Madni's location, and asked them to arrest him. ${ }^{292}$ Several days later, Egypt made a formal request that Indonesia extradite Madni to them for unspecified, terrorism-related crimes. ${ }^{293}$ However, according to "a senior Indonesian government official," "[t]his was a U.S. deal all along...Egypt just provided the formalities." 294 On January 11, the Indonesian officials said, Madni was taken onto a U.S. registered Gulfstream V jet at a military airport, and flown to Egypt. ${ }^{295}$

When the Washington Post article was written, in March of 2002, “intelligence sources" told reporters that "Iqbal remains in custody in Egypt... The sources said he has been questioned by

\footnotetext{
287 Michael Isikoff, Periscope: Terror: Swapping Stories, Newsweek, July 25, 2004.

288 Jane Mayer, Outsourcing Torture, THE NEW YoRKER, Feb. 14, 2005, at 116.

289 Id. at 117.

290 Rajiv Chandrasekaran \& Peter Finn, U.S. Behind Secret Transfer of Terror Suspects, WASH. PoST, Mar. 11, 2002 , at A1.

291 Id.

292 Id.

293 Id.

294 Id.
} 
U.S. agents but there was no word on his legal status." ${ }^{296}$ On September 11, 2004, the Times of London reported that despite repeated inquiries by Madni's relatives, "nothing has been seen or heard from" him since he was taken from Jakarta. ${ }^{297}$ In November 2004, Kalla Fakta reported that "[a]ccording to rumours in the intelligence communities in the west, Iqbal [Madni] died during interrogations in Egypt."298

I believe that Madni may actually have been transferred from Egypt to Guantánamo Bay. I base this on the following excerpts from Shafiq Rasul's, Asif Iqbal's, and Rhuhel Ahmed's statement:

\begin{abstract}
Moazzam Begg we never saw. We only heard about him, particularly from Saad Al Madini, who was a Pakistani brought up in Saudi Arabia. He had been in Bagram Airbase with Moazzam Begg and he had himself been taken from Bagram Airbase. He had been we think handed over by Indonesia to the Americans, kept in Bagram Airbase, taken from Bagram airbase to Egypt where he had been tortured and then taken back to Bagram and then to Guantanamo.....299
\end{abstract}

Asif recollects that "another man who'd be taken to Egypt and tortured there, Saad Al Madini, was also refused medical assistance for the same reason [as Mamdouh Habib]. We know from Al Madini that he had had electrodes put on his knees and that something had happened to his knees and something had happened to his bladder and he had problems going to the toilet. He told us that when he was in interrogation he was told by interrogators that if he cooperated he would be first in line for medical treatment. ${ }^{300}$

I could not find "Saad al Madini," or any name similar to it, on any of the lists of Guantánamo

prisoners. A Washington Post researcher whom I contacted about this told me that they could find no similar names in their list of Guantánamo detainees. ${ }^{301}$ Based on this, the similarity of the names "Muhammad Saad Iqbal Madni" and "Saad al Madini," and the description of the prisoner being transported by Americans from Indonesia to Egypt, ${ }^{302}$ I believe that they are the same 
person.

The Guardian reported on September 12, 2005, that Madni "was held in Cairo for two years before appearing in Guantánamo, where he told other detainees who have since been released that he was tortured by having electrodes placed on his knees. It also appears that his bladder was damaged during interrogation." 303 This seems to be based partly on Shafiq Rasul's, Asif Iqbal's, and Rhuhel Ahmed's statement; I do not know whether the Guardian found additional information confirming that it was Madni whom the three Britons encountered.

e. Name Unknown (2002 or 2003)

Former CIA agent Vincent Cannistraro has described a senior al-Qaeda suspect held in Guantánamo Bay who was sent to Egypt after refusing to cooperate with U.S. interrogators. ${ }^{304 "}$ They promptly tore his fingernails out," Cannistraro told Newsday, "and he started to tell things." 305

f. Osama Moustafa Nasr (February 2003)

Osama Moustafa Nasr, an Egyptian cleric with al-Qaeda ties then living in Milan, was taken into U.S. custody in Milan on February 17, 2003. ${ }^{306}$ Two witnesses told Italian police that they saw several intelliegnce agents spray Nasr in the face with some sort of chemical, and force him into a nearby van. ${ }^{307}$ According to Italian court documents, Nasr was then driven to Aviano, a U.S. airforce base. ${ }^{308}$ CIA agents flew him from Aviano to another U.S. air base in Ramstein,

Those suspects, Omar al-Faruq of Kuwait and Iqbal Madni of Pakistan, were not Indonesian citizens. Bashir, on the other hand, is an Indonesian and a major public figure in his hometown of Solo, in central Java, where he ran a religious boarding school. Farah Stockman, Cleric's Trial Tests US Antiterror Fight, Boston Globe, Mar. 2, 2005 at A1. This suggests that Faruq and Iqbal Madni were the only two suspects that Indonesia turned over to the United States. If that is accurate, it increases the chances that the "Saad al Madini" whom Rasul, Iqbal and Ahmed encountered is, in fact, Muhammad Saad Iqbal Madni.

303 Ian Cobain, Stephen Gray, and Richard Norton-Taylor, Destination Cairo: Human Rights Fears Over CIA Flights, GUARDIAN, Sept. 12, 2005, available at $\mathrm{http}: / / \mathrm{www} . g u a r d i a n . c o . u k / \mathrm{uk}$ news/story/0,3604,1567849,00.html.

304 Knut Royce, Mixed Reviews From Experts. Critics: Make Case on Deceit, Not Terror, NewSDAY, Feb. 6, 2003.

305 Id.

306 Stephen Grey and Don Van Natta, 13 With the CIA Sought by Italy in a Kidnapping, N.Y. Times, June 25, 2005 at A1.

307 Id.

${ }^{308}$ Id. 
Germany, and then from Ramstein to Cairo, where he was imprisoned by Egyptian security forces. ${ }^{309}$

In April 2004, Nasr was temporarily released from prison in Egypt and called his wife and at least one other Muslim cleric in Italy. ${ }^{310}$ Italian police intercepted the calls. ${ }^{311}$ Nasr said he had been tortured so badly that he lost hearing in one year, had been subjected to electric shocks, and was barely able to walk. ${ }^{312}$

Shortly after these phone calls were made, Nasr was re-arrested in Egypt ${ }^{313}$ His brother told reporters in July 2005 that he was still in prison. ${ }^{314}$

In June 2005, an Italian judge issued arrest warrants for thirteen CIA agents involved in Nasr's abduction. ${ }^{315}$ They have been charged with kidnapping. ${ }^{316}$ The agents have left Italy, and the United States is unlikely to extradite them. ${ }^{317}$

\section{Renditions to Syria}

The State Department's 2001 - 2004 Country Reports on Human Rights Practices for Syria

describe severe torture by the country's intelligence service. ${ }^{318}$ The 2004 report states,

According to Amnesty International (AI) and the Human Rights Association of Syria (HRAS), there were eight persons who died in detention due to torture or mistreatment by the security services during the year.... Former prisoners and detainees, as well as the HRAS, reported that torture methods included administering electrical shocks; pulling out fingernails; forcing objects into the rectum; beating, sometimes while the victim was suspended from the ceiling; hyperextending the spine; bending the detainees into the frame of a wheel and whipping exposed body parts; and using a backward-bending chair to asphyxiate the victim or fracture the victim's spine. Torture was most likely to occur while detainees were being held at one of the many detention centers run by the various security services throughout the country, particularly while the authorities were attempting to

309 Id.

310 Paddy Agnew, Judge Orders Arrest of 13 CIA Agents, IRISH TimES, Jun. 25, 2005, at 10.

311 Id

312 Stephen Grey and Don Van Natta, 13 With the CIA Sought by Italy in a Kidnapping, N.Y. TimES, June 25, 2005 at A1.

313 Id.

314 Lawyer Says Alleged CIA Abductee Is in Egypt Prison, Houston Chronicle, July 3, 2005, at 25.

315 Id.

316 Id.

${ }^{317}$ Dana Priest, Italy Knew About Plan to Grab Suspect, WASH. Post, June 30, 2005, at A1 ("The paramilitary team and other CIA operatives who participated are also long gone, and it is highly unlikely the U.S. government would confirm their identities or extradite them for trial.”).

318 U.S. DePartment OF STATE, Country Reports on Human Rights Practices: SyRia -- 2004 (Feb. 2005); U.S. DePARTMENT OF STATE, COUNTRY REPORTS ON HUMAN RightS PRACTICES: SYRIA -- 2003 (Feb. 2004); U.S. DEPARTMENT OF STATE, COUNTRY REPORTS ON HUMAN

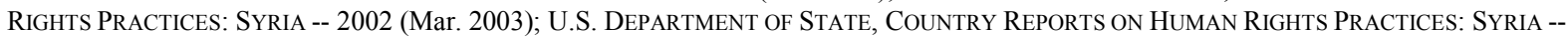
2001 (Mar. 2002). All of the State Department's Country Reports from 1993 - 2004 are available at http://www.state.gov/g/drl/hr/c1470.htm. 
extract a confession or information. ${ }^{319}$

In addition to the alleged torture of Maher Arar, Abdullah Almalki, and Ahmad el-Maati

discussed in Section I, there is one known case of rendition to Syria:

a. Muhammad Haydar Zammar (November 2001)

Muhammad Haydar Zammar, a German citizen of Syrian descent ${ }^{320}$ suspected of recruiting

Muhammad Atta and several other September 11 hijackers into al-Qaeda, ${ }^{321}$ was arrested in

Morocco in November of 2001 and flown to Syria fifteen days later. ${ }^{322}$ Moroccan government

sources have told reporters that the CIA asked them to arrest Zammar and send him to Syria, ${ }^{323}$ and that

CIA agents took part in his interrogation sessions in Morocco. ${ }^{324}$ Moroccan officials said that the

stated basis for sending Zammar to Syria was a twenty-year-old charge that he was a member of the

Muslim Brotherhood, a banned Islamist group, but Zammar did not receive an extradition hearing. ${ }^{325}$

Zammar was taken to the Palestine Branch, the same Syrian prison where Maher Arar would

later be held. ${ }^{326}$ On July 1, 2002, Time magazine reported,

US. officials tell Time that no Americans are in the room with the Syrians who interrogate Zammar. U.S. officials in Damascus submit written questions to the Syrians, who relay Zammar's answers back. State Department officials like the arrangement because it insulates the U.S. government from any torture the Syrians may be applying to Zammar. And some State Department officials suspect that Zammar is being tortured. ${ }^{327}$

The Daily Telegraph and Washington Post have also reported that U.S. agents were telling

Syrian interrogators what questions to ask Zammar. ${ }^{328}$

319 U.S. Department of State, Country Reports on Human Rights Practices: Syria -- 2004 (Feb. 2005),

http://www.state.gov/g/drl/rls/hrrpt/2004/41732.htm.

320 As in Arar's case, Zammar was technically a dual citizen because Damascus does not allow those born in Syria to renounce their citizenship.

321 See, e.g., George Tenet, Testimony to 9/11 Commission (unclassified version) (June 18, 2002) (transcript available at

http://www.cia.gov/cia/public_affairs/speeches/2002/dci_testimony_06182002.html).

322 Peter Finn, Al Qaeda RecruiterReportedly Tortured; Ex-Inmate in Syria Cites Others' Accounts, WASH. Post, Jan. 31, 2003 , at A14.

323 Douglas Frantz, War of Secrets: Sharing Information; Learning to Spy with Allies, N.Y. TimES, Sept. 8, 2002, at page 1 of Week in Review section; John Crewsdon, Bid for New Witness Could Slow Plot Trial; Defense Sets Sights on Radical in Syria, CHICAGO TRIBUNE, Jan. $29,2003$.

324 Peter Finn, Al Qaeda RecruiterReportedly Tortured; Ex-Inmate in Syria Cites Others' Accounts, WASH. Post, Jan. 31, 2003 , at A14.

325 Id. A Moroccan human rights group told Finn that "suspects are supposed to be brought before a hearing 72 hours after arrest." Id.

326 Press Release, Amnesty International, Appeal Case -- Syria: Syrian German Held Three Years Without Charge in Rat-Infested Syrian "Tomb" (Oct. 8, 2004).

327 Mitch Frank, Help From an Unlikely Ally, TiME, July 1, 2002.

328 David Rennie \& Toby Helm, War on Terrorism: Syrians Reveal Secret Help in al-Qa'eda Hunt, DAILY TELEGRAPH, June 20, 2002 , at 14

("American agents had been allowed to submit written questions to Zammar and had received a steady flow of information in return"); Glenn

Kessler, U.S.-Syria Relations Not Quite as Cold, WASH. Post, June 20, 2002, at A15 ("While U.S. officials have not been able to question 
In January 31, 2003, a Moroccan citizen named Driss bin Lakoul told the Washington Post

that he had been imprisoned at the Palestine Branch for three months starting in January 2002.329

Lakoul said that he had not encountered Zammar directly, but had heard other prisoners describe a

German citizen being held in the prison basement and taken out of his cell only to be interrogated and tortured: 330

There were five brothers in the prison's underground area who saw [Zammar], three Saudis and two Yemenis. They could talk with him down there; the walls were not thick. A brother from Saudi Arabia was in the cell next to him, and this brother from Saudi Arabia also how this man was taken away to torture. ${ }^{331}$

Amnesty International reported in October 2004 that Zammar

remains detained in cell number 13 of the tiny cells referred to as 'tombs' or 'graves' by the detainees and prison guards...Zammar's underground cell is believed to be $185 \mathrm{~cm}$ long, less than $90 \mathrm{~cm}$ wide, and under two metres high. ${ }^{332}$

Amnesty stated that Zammar, who weighed 300 pounds at the time of his arrest,,333 "is now

said to be 'skeletal'." 334

In April 2005, Amnesty International alleged that Zammar was moved from his underground cell in the Palestine Branch to an unknown location in October 2004. ${ }^{335}$

\section{Renditions to Uzbekistan}

Craig Murray, the United Kingdom's former Ambassador to Uzbekistan, ${ }^{336}$ has told reporters

he knows of several specific cases where the U.S. transferred prisoners to Uzbekistan. Murray

\footnotetext{
Zammar, Americans have submitted questions to the Syrians"), Howard Schneider, Syria Evolves as Anti-Terror Ally, WASH. POST, July 25, 2002, at A18 ("it is unclear whether U.S. officials are being allowed to question [Zammar] in person or merely pose questions through Syrian interrogators").

329 Peter Finn, Al Qaeda RecruiterReportedly Tortured; Ex-Inmate in Syria Cites Others' Accounts, WASH. Post, Jan. 31, 2003 , at A14. ${ }^{330} I d$.

$331 \mathrm{Id}$.

332 Press Release, Amnesty International, Appeal Case -- Syria: Syrian German Held Three Years Without Charge in Rat-Infested Syrian "Tomb" (Oct. 8, 2004).

333 Douglas Frantz \& Desmond Butler, The 9/11 Inquest: Now Americans Say Germans Bungled, N.Y. TimES, July 11, 2002 , at A9.

334 Press Release, Amnesty International, Appeal Case -- Syria: Syrian German Held Three Years Without Charge in Rat-Infested Syrian "Tomb" (Oct. 8, 2004).

335 Press Release, Amnesty International, Appeal Case Update -- Syria/Germany/USA: "Disappearance" of Muhammad Haydar Zammar, (Apr. 6, 2005) (availale at http://web.amnesty.org/library/pdf/MDE240162005ENGLISH/\$File/MDE2401605.pdf).

336 Murray resigned from the United Kingdom's Foreign Office in 2004, after the Foreign Office investigated charges that he had mismanaged the embassy. The investigation may have been connected to Murray's previous denunciations of the Karimov regime's human rights practices, and of British and American intelligence's collaboration with the Uzbek government. It was closed without any disciplinary action against Murray. See Don Van Natta Jr., How Ally With Abuse Record Became A Surrogate U.S. Jailer, N.Y. TimES, May 1, 2005.
} 
told The New Yorker that he knew of "at least three" renditions to Uzbekistan. ${ }^{337}$ He later told the CBS news program 60 Minutes that "I know of two instances for certain of prisoners who were brought back in a small jet" operated by a company Murray called "Premier Executive Airlines." ${ }^{38}$ A Gulfstream V Jet owned by a Massachusetts company called Premier Executive Transport Services is known to have been used in many renditions. ${ }^{339}$ Murray stated that Uzbekistan routinely tortured prisoners using brutal means including "drowning and suffocation, rape was used quite commonly, and also immersion of limbs in boiling liquid." $340 \mathrm{He}$ also charged that

The CIA definitely knows. I asked my deputy to go and speak to the CIA. And she came back and reported to me that she met the CIA head of station, who told her that yes, this material probably was obtained under torture, but the CIA didn't see that as a problem. ${ }^{341}$

However, CIA officials told CBS that this meeting never took place. ${ }^{342}$

Flight records obtained by the New York Times show that two planes used by the CIA in renditions landed at the Tashkent, Uzbekistan airport on September 21, 2003. ${ }^{343}$ One of the planes had departed for Tashkent from Baghdad, the other from the Czech Republic. ${ }^{344}$ It is not clear whether these are the renditions that Murray described, or separate cases. Flight records for the planes used in renditions show at least seven to ten total trips to Uzbekistan, ${ }^{345}$ and Murray has told the Times that in 2003 and early 2004 CIA flights landed in Tashkent an average of twice a week. ${ }^{346}$

The 2001 - 2004 State Department Country Reports on Human Rights Practices for Uzbekistan all allege widespread, extremely brutal and in some cases fatal torture of prisoners. ${ }^{347}$ The 2004 report

\footnotetext{
337 Jane Mayer, Outsourcing Torture, THE NEW YORKER, Feb. 14, 2005, at 116.

33860 Minutes: CIA Flying Suspects to Torture? (CBS television broadcast, Mar. 6, 2005, transcript available at http://www.cbsnews.com/stories/2005/03/04/60minutes/main678155.shtml).

339 Id.

340 Id.

341 Id.

342 Id.

343 Don Van Natta Jr., How Ally With Abuse Record Became A Surrogate U.S. Jailer, N.Y. TIMES, May 1, 2005.

${ }^{344} I d$. The planes used in renditions tends to stop in European airports to re-fuel, so the stop in the Czech Republic may have been for that purpose.

${ }^{345}$ Id. See also 60 Minutes: CIA Flying Suspects to Torture? (CBS television broadcast, Mar. 6, 2005, transcript available at http://www.cbsnews.com/stories/2005/03/04/60minutes/main678155.shtml).

346 Id.

347 U.S. Department of State, Country Reports on Human Rights Practices: UzBeKistan -- 2004 (Feb. 2005); U.S. DePartment of
} 
charged that

police and the NSS routinely tortured, beat, and otherwise mistreated detainees to obtain confessions or incriminating information. Police, prison officials, and the NSS allegedly used suffocation, electric shock, rape, and other sexual abuse; however, beating was the most commonly reported method of torture. ${ }^{348}$

All four reports noted that the worst human rights abuses were committed against those believed to

have ties to Islamic extremism, especially accused members of the Islamist group Hizb ut-Tahrir.

\section{According to the 2003 report,}

Authorities reportedly routinely beat and treated prisoners suspected of extremist Islamic political sympathies, particularly alleged members of Hizb ut-Tahrir, more harshly than criminals, regardless of whether investigators were seeking a confession. A majority of the cases over the past few years in which persons were likely tortured to death while in custody involved suspected Hizb ut-Tahrir members. Local human rights workers reported that common criminals -- known as "prison boxers" -- were often paid or otherwise induced to beat Hizb ut-Tahrir members. ${ }^{349}$

The 2001, 2002, 2003, and 2004 country reports describe the following specific instances of fatal

torture of Hizb ut-Tahrir suspects:

Emin Usman was arrested on February 21, 2001 on charges of belong to Hizb ut-Tahrir. He died in custody approximately one week later. Police claimed he committed suicide, but a family member who saw his body "reported that it bore clear signs of having been beaten." 350

Shovruk Ruzimuradov, accused of possessing Hizb ut-Tahrir leaflets, died in custody on July 7, 2001.

An official investigation of his death concluded that he committed suicide, but family members said his

body showed clear evidence of torture. ${ }^{351}$

On October 16, 2001,

police arrested two brothers, Ravshon and Rasul Haitov, on suspicion of Hizb ut-Tahrir membership. On October 17, police returned the body of Ravshon Haitov to his family, which showed clear signs of torture; authorities informed the family that he had died of a heart attack. His brother Rasul was beaten so severely that he became an

State, Country Reports on Human Rights Practices: Uzbekistan -- 2003 (Feb. 2004); U.S. DePartment OF State, Country Reports

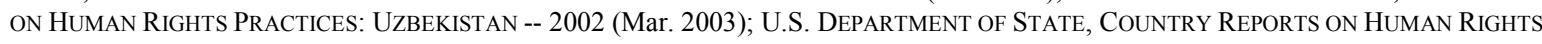
PRACTICES: UZBEKISTAN -- 2001 (Mar. 2002). All of the State Department's human rights reports from 1993 - 2004 are available at $\mathrm{http}: / / \mathrm{www} \cdot$ state.gov/g/drl/hr/c1470.htm.

348 U.S. Department of State, Country Reports on Human Rights Practices: UzBeKistan -- 2004 (Feb. 2005), http://www.state.gov/g/drl/rls/hrrpt/2004/41717.htm

349 U.S. Department of State, Country Reports on Human Rights Practices: UZBEKistan -- 2003 (Feb. 2004), http://www.state.gov/g/drl/rls/hrrpt/2003/27873.htm.

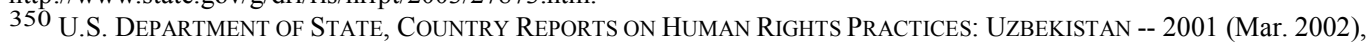
http://www.state.gov/g/drl/rls/hrrpt/2001/eur/8366.htm.

351 U.S. DePARTMENT OF STATE, COUNTRY REPORTS ON HuMAN RightS PRACTICES: UZBEKISTAN -- 2002 (Mar. 2003),

http://www.state.gov/g/drl/rls/hrrpt/2002/18400.htm; U.S. DEPARTMENT OF STATE, COUNTRY REPORTS ON HUMAN RighTS PRACTICES:

UZBEKISTAN -- 2001 (Mar. 2002), http://www.state.gov/g/drl/rls/hrrpt/2001/eur/8366.htm. 
invalid. ${ }^{352}$

The bodies of Hizb ut-Tahrir prisoners Mirzakomil Avazov and Khusnuddin Olimov were returned to their families on August 7,2002. They "were badly beaten and had burns attributable to scalding water over significant portions of their bodies." Police claimed "that the men died in an altercation with two other inmates and that in the course of the fight hot water from a tea cauldron was spilled on them," and this was still the government's official explanation two years later. However "independent analysis by experts in the United Kingdom of photographs taken shortly after their deaths concluded that the men had likely been suspended in boiling water."353

On May 15, 2003, Hizb ut-Tahrir member Orif Ershanov died of injuries suffered during a severe beating by security forces. Relatives' photographs showed bruises on Ershanov's chest, legs, and the soles of his feet, broken ribs, wounds on the arm and back, and "evidence that sharp objects had been inserted under the fingernails." 354 The official medical examiners report claimed that the cause of death was high blood pressure. ${ }^{355}$

This may be an understatement of the number of torture deaths. The 2003 report noted,

In some cases, law enforcement officials warned families not to talk about their relatives' deaths, which were often attributed by government officials to purely natural causes...examiners' reports routinely misstated the cause of death or covered up abuses. In many cases (including death penalty cases), families were not told of their relative's death until after the body had been buried, making independent forensic investigation almost impossible. As a result, rumors of detainees dying in custody as a result of mistreatment abounded but were generally impossible to confirm. In no case in which a death in custody appeared to be due in whole or in part to torture or other mistreatment was the death officially attributed to such causes. ${ }^{356}$

The State Department reports detail many other instances of severe torture of Hizb ut-Tahrir members that the victim survived, and several other deaths in custody.

\footnotetext{
352 U.S. Department of State, Country Reports on Human Rights Practices: UzBekistan -- 2001 (Mar. 2002), $\mathrm{http}: / / \mathrm{www} . \mathrm{state} . \mathrm{gov} / \mathrm{g} / \mathrm{drl} / \mathrm{rls} / \mathrm{hrrpt} / 2001 / \mathrm{eur} / 8366 . \mathrm{htm}$.

353 U.S. DePARTMENT OF STATE, COUNTRY REPORTS ON HuMAN Rights PRACTICES: UZBEKISTAN -- 2004 (Feb. 2005); U.S. DEPARTMENT OF State, Country Reports on Human Rights PRACTICES: UzBeKistan -- 2002 (Mar. 2003). All of the State Department's Country Reports from 1993 - 2004 are available at http://www.state.gov/g/drl/hr/c1470.htm.

354 U.S. DePartment of State, Country RePorts On Human Rights Practices: UZBeKistan -- 2003 (Feb. 2004), http://www.state.gov/g/drl/rls/hrrpt/2003/27873.htm..

$355 I d$.

$356 \mathrm{Id}$
} 


\section{Renditions to Jordan}

The 2001, 2002, 2003 and 2004 State Department human rights reports for Jordan all discuss credible allegations of torture by prisoners there. ${ }^{357}$ According to the 2001 report, for example, prisoners there made allegations of "methods of torture include sleep deprivation, beatings on the soles of the feet, prolonged suspension with ropes in contorted positions, and extended solitary confinement." 358

There is one case of rendition to Jordan where the prisoner's name is known:

a. Jamil Qasim Saeed Muhammad (October 2001)

At one a.m. in the morning of October 23, 2001, Pakistan handed Jamil Qasim Saeed

Muhammad over to U.S. officials in a dark corner of the Karachi airport. ${ }^{359}$ Muhammad, a Yemeni microbiology student and an alleged suspect in the U.S.S. Cole bombing, ${ }^{360}$ had been missing from Karachi University since early October. ${ }^{361}$ Pakistani officials told the Washington Post that Muhammad was handed over without deportation or extradition proceedings. ${ }^{362} \mathrm{He}$ was shackled and blindfolded. ${ }^{363}$ An eyewitness told Pakistan's News International that "the entire operation was so mysterious that all persons involved in the operation, including U.S. troops, were wearing masks," and that a masked American agent filmed the handover. ${ }^{364}$ The witness said Muhammad was placed onto a private jet with the tail number N379P, which departed to

\footnotetext{
357 U.S. Department OF State, Country Reports on Human Rights Practices: Jordan -- 2004 (Feb. 2005); U.S. Department OF

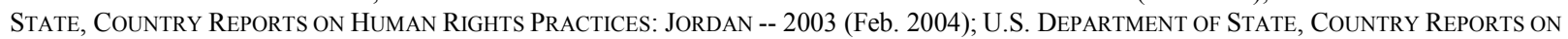
Human Rights Practices: Jordan -- 2002 (Mar. 2003); U.S. Department of State, COUNTRY RePORTS On Human Rights PRACTICES: JORDAN -- 2001 (Mar. 2002). All of the State Department's Country Reports from 1993 - 2004 are available at http://www.state.gov/g/drl/hr/c1470.htm.

358 U.S. DEPARTMENT OF STATE, COUNTRY REPORTS ON HuMAN Rights PRACTICES: JORDAN -- 2001 (Mar. 2002), http://www.state.gov/g/drl/rls/hrrpt/2001/nea/8266.htm.

359 Alissa Rubin, Response to Terror: Pakistan Hands Over Man in Terror Probe, L.A. TIMES, Oct. 28, 2001, at 4.

360 Rajiv Chandrasekaran \& Peter Finn, U.S. Behind Secret Transfer of Terror Suspects, WASH. Post, Mar. 11, 2002 , at A1.

361 Alissa Rubin, Response to Terror: Pakistan Hands Over Man in Terror Probe, L.A. TIMES, Oct. 28, 2001, at 4.

362 Rajiv Chandrasekaran \& Peter Finn, U.S. Behind Secret Transfer of Terror Suspects, WASH. Post, Mar. 11, 2002 , at A1.

363 Rajiv Chandrasekaran \& Peter Finn, U.S. Behind Secret Transfer of Terror Suspects, WASH. Post, Mar. 11, 2002, at A1.

364 Masood Anwar, Mystery Man Handed Over to U.S. Troops in Karachi, The News InTERNATIONAL (Pakistan), Oct. 26, 2001. In an interview with a Swedish TV show, Anwar later identified his sources for the article as members of the airport "firebrigade." Kalla Fakta: The Broken Promise, Part I (television broadcast on Sweden's TV 4, May 17, 2004, English transcript available at
} 
Amman, Jordan at 2:40 a.m. ${ }^{365}$ This is the same plane that later transported Ahmad Agiza and Muhammad al-Zery to Egypt. ${ }^{366}$

Muhammad has not been seen since. Amnesty International asked the U.S. about his current location and legal status, but received no reply. ${ }^{367}$

As noted in Section I, Canadian government documents and the Israeli newspaper Ha'aretz have indicated that the CIA may be operating an interrogation or debriefing station for al-Qaeda suspects in Jordan. ${ }^{368}$ It is possible that Muhammad was held there rather than in Jordanian custody. Since CIA detention centers are sometimes staffed by foreign nationals, ${ }^{369}$ there is no bright line between this sort of detention and rendition, and there are several other cases where transfers to secret CIA detention centers have initially been reported as renditions. ${ }^{370}$

\section{Renditions to Morocco}

The 2001, 2002, 2003 and 2004 State Department human rights reports for Morocco all discuss credible allegations of torture by prisoners there. ${ }^{371}$ According to the 2003 report, incidents of torture had recently risen, and those accused of terrorism were especially likely to be tortured:

http://www.hrw.org/english/docs/2004/05/17/sweden8620.htm).

365 Masood Anwar, Mystery Man Handed Over to U.S. Troops in Karachi, The News InTERnATIOnAL (Pakistan), Oct. $26,2001$.

366 See Section III(B)(1)(b), supra.

367 AmNesty InTERnATIONAL, United States of America: The Threat of A BAD EXAmple 32 (Aug. 2003), http://web.amnesty.org/library/pdf/AMR511142003ENGLISH/\$File/AMR5111403.pdf.

368 Yossi Melman, CIA: No Comment on Report 11 Qaida Suspects Held in Jordan, HA'ARETZ, Oct. 13, 2004, Michelle Shepard, Arar May Have Spent Time at Secret CIA Facility, TORONTO STAR, Oct. 15, 2004.

369 E.g., Dana Priest, CIA Avoids Scrutiny of Detainee Treatment, WASH. Post, Mar. 2, 2005, available at http://www.washingtonpost.com/wpdyn/articles/A2576-2005Mar2.html (referring to "Afghan guards -- paid by the CIA and working under CIA supervision in an abandoned warehouse code-named the Salt Pit").

${ }^{370}$ For example, Khaled el-Masri, a German used car salesman, was mistaken for an al-Qaeda training camp leader with the same name and flown from Macedonia to the CIA prison in Afghanistan known as the salt pit. The case was initially described as a rendition. See Don Van Natta, Jr. \& Souad Mekhennet, German's Claim of Kidnapping Brings Investigation of U.S. Link, N.Y. TIMES, Jan. 9, 2005, at A1, James Meek, 'They Beat Me From All Sides', The Guardian, Jan. 14, 2005, at 2, 60 Minutes: CIA Flying Suspects to Torture? (CBS television broadcast, Mar. 6, 2005, transcript available at $\mathrm{http}: / / \mathrm{www} . c b s n e w s . c o m /$ stories/2005/03/04/60minutes/main678155.shtml).

371 U.S. Department of State, COUnTRY Reports on Human Rights Practices: Morocco -- 2004 (Feb. 2005); U.S. DEPARTMENT OF State, Country Reports on Human Rights Practices: Morocco -- 2003 (Feb. 2004); U.S. Department OF STATE, CounTRy Reports on Human Rights Practices: Morocco -- 2002 (Mar. 2003); U.S. Department of State, Country Reports On Human Rights PRACTICES: MOROCCO -- 2001 (Mar. 2002). All of the State Department's Country Reports from 1993 - 2004 are available at 
Attorneys for some persons convicted under the new anti-terrorism law claimed their clients were convicted on the basis of confessions coerced by torture. For example, according to the [Moroccan Human Rights Organization], in early August, at the Court of Appeal in Fez, most of the 29 accused of terrorist involvement stated that they had been tortured; judicial authorities refused to order any medical examinations.

In October after a mission to the country, [Amnesty International] reported a sharp rise in the number of cases of torture or ill treatment in the last 2 years. ${ }^{372}$

Since September 11, one suspect has publicly alleged being sent to Morocco and tortured:

a. Benyam Muhammad (July 2002)

Benyam Muhammad, an Ethiopian national who had been granted asylum in Great Britain,

was arrested at the Karachi, Pakistan airport in April 2002. Muhammad alleged, as reported to

the Guardian from notes compiled by British human rights attorney Clyde Stafford Smith, that

he was held at two prisons in Pakistan over three months, hung from leather straps, beaten, and threatened with a firearm by Pakistanis. In repeated questioning by men he believes were FBI agents, he was told he was to go to an Arab country because "the Pakistanis can't do exactly what we want them to".

The torture stopped after a visit by two bearded Britons; he believes they were MI6 officers. He says they told him he was to be tortured by Arabs. ${ }^{373}$

According to the Washington Post FBI agents originally threatened Muhammad with rendition to

Jordan, ${ }^{374}$ but in July 2002 he was flown to a prison in Morocco on a U.S. military plane. In Morocco,

U.S. officials accused him of being an accomplice of Jose Padilla, a U.S. citizen who has been held has an

"enemy combatant" for several years. ${ }^{375}$ As the Post noted, in a June 1, 2004 press conference, Deputy

Attorney General James Comey stated that Padilla had an accomplice who "had refugee status in the

United Kingdom", who was "in custody" but whose identity was classified. 376

In Morocco, Muhammad has alleged, interrogators deliberately cut him with a scalpel:

They took the scalpel to my right chest. It was only a small cut. Maybe an inch. At first I just screamed . . . I was just shocked, I wasn't expecting ... Then they cut my left chest. This time I didn't want to scream because I knew it was coming.

One of them took my penis in his hand and began to make cuts. He did it once, and they stood still for maybe a

http://www.state.gov/g/drl/hr/c1470.htm.

372 U.S. Department of State, Country Reports on Human Rights Practices: Morocco -- 2003 (Feb. 2004), http://www.state.gov/g/drl/rls/hrrpt/2003/27934.htm.

373 Stephen Gray and Ian Cobain, Suspect's Tale of Travel and Torture, THE GUARDIAN, Aug. 2, 2005 at 1, available at http://www.guardian.co.uk/uk_news/story/0,3604,1540550,00.html.

${ }^{374}$ Kevin Sullivan, Detainee Alleges Abuse En Route to Guantanamo, WASH. Post, Aug. 3, 2005 at 13, available at http://www.washingtonpost.com/wp-dyn/content/article/2005/08/02/AR2005080201702.html.

375 Id.

376 Deputy Attorney General James Comey, News Conference on Jose Padilla (June 1, 2004) (transcript available at http://www.cnn.com/2004/LAW/06/01/comey.padilla.transcript/). 
minute, watching my reaction. I was in agony. They must have done this 20 to 30 times, in maybe two hours. There was blood all over. "I told you I was going to teach you who's the man," [one] eventually said.

They cut all over my private parts. One of them said it would be better just to cut it off, as I would only breed terrorists. I asked for a doctor. ${ }^{377}$

Muhammad said that this was repeated "about once a month" during the eighteen months he was in

Morocco. ${ }^{378}$

Stafford Smith stated that he had seen scars on Muhammad's body consistent with these

allegations. ${ }^{379}$

In January 2004, Muhammad was flown to Bagram Air Force Base in Kabul, Afghanistan. He stated that when the plane picked him up,

a female MP took pictures. She was one of the few Americans who ever showed me any sympathy. When she saw the injuries I had she gasped. They treated me and took more photos when I was in Kabul. Someone told me this was "to show Washington it's healing."380

He was transferred to Guantánamo Bay in September 2004, and is currently being held there. ${ }^{381}$

\section{C.U.S. OfFicials' Statements on the Reliability of Diplomatic AsSURANCES}

Several U.S. intelligence agents involved in renditions have told reporters that the CIA has never believed that diplomatic assurances would prevent countries from torturing prisoners. For example, Vincent Cannistraro, the former head of the CIA's counterterrorism division, told the Glasgow Herald in October 2002 that "Egyptian jails are full of guys missing toenails and fingernails. It's crude, but highly effective, although we could never condone it publicly. The Egyptians and Jordanians are not that squeamish.” 382 In relation to Arar's case, Cannistraro later told Knight-Ridder that "[y]ou would have to be deaf, dumb and blind to believe that the Syrians

\footnotetext{
377 “One of Them Made Cuts in My Penis. I Was in Agony," THE GuARDIAn, Aug. 2, 2005, available at http://www.guardian.co.uk/terrorism/story/0,12780,1540552,00.html. ${ }^{378} I d$.

379 Kevin Sullivan, Detainee Alleges Abuse En Route to Guantanamo, WASH. Post, Aug. 3, 2005 at 13, available at http://www.washingtonpost.com/wp-dyn/content/article/2005/08/02/AR2005080201702.html.

380 "One of Them Made Cuts in My Penis. I Was in Agony," The GuARDiAn, Aug. 2, 2005, available at $\mathrm{http}: / /$ www.guardian.co.uk/terrorism/story/0,12780,1540552,00.html.

${ }^{381}$ Kevin Sullivan, Detainee Alleges Abuse En Route to Guantanamo, WASH. Post, Aug. 3, 2005 at 13, available at http://www.washingtonpost.com/wp-dyn/content/article/2005/08/02/AR2005080201702.html.

382 Ian Bruce, Middleman Reveals Al Qaeda Secrets, THE HeRALD (Glasgow), Oct. 17, 2002, at 6.
} 
were not going to use torture, even if they were making claims to the contrary." 383

On December 26, 2002, the Washington Post reported the following quotations from CIA agents and administration officials:

"If you don't violate someone's human rights some of the time, you probably aren't doing your job," said one official who has supervised the capture and transfer of accused terrorists....

According to one official who has been directly involved in rendering captives into foreign hands, the understanding is, "We don't kick the [expletive] out of them. We send them to other countries so they can kick the [expletive] out of them."...

One official who has had direct involvement in renditions said he knew they were likely to be tortured. "I ... do it with my eyes open," he said....

Bush administration officials said the CIA, in practice, is using a narrow definition of what counts as "knowing" that a suspect has been tortured. "If we're not there in the room, who is to say?" said one official conversant with recent reports of renditions. ${ }^{384}$

Dan Coleman, a former FBI agent who worked with the CIA on terrorism cases, told the New

Yorker that there was never any question that Egypt tortured prisoners. The CIA "loved that

these guys would just disappear off the books, and never be heard of again. They were proud of it,"

Coleman stated. ${ }^{385}$ Retired CIA agent Robert Baer said that agents know exactly what to expect

from each country's intelligence services: "If you want a serious interrogation, you send a

prisoner to Jordan. If you want them to be tortured, you send them to Syria. If you want someone to disappear -- never to see them again -- you send them to Egypt."386

Michael Scheuer, the former head of the CIA unit charged with dismantling al-Qaeda and other Islamist terror networks, told 60 Minutes in March 2005 that if rendition resulted in useful information, "It's OK with me...I'm responsible for protecting Americans." 387 But "the idea that we're gonna suddenly throw our hands up like Claude Raines in 'Casablanca' and say, 'I'm shocked that justice in Egypt isn't like it is in Milwaukee,' there's a certain disingenuousness to that," he

\footnotetext{
383 Shannon McCaffrey, Canadian Sent to Syrian Prison Disputes U.S. Claims Against Torture, KNight-RidDer, Aug. 1, 2004.

${ }^{384}$ Dana Priest \& Barton Gellman, U.S. Decries Abuse But Defends Interrogations, WASH. POST, December 26, 2002, at A1, available at http://www.washingtonpost.com/ac2/wp-dyn/A37943 - 2002Dec25?language=printer.

385 Jane Mayer, Outsourcing Torture, THE NEW YORKER, Feb. 14, 2005, at 110.

386 Stephen Grey, America's Gulag, New StATESMAN, May 17, 2004.

38760 Minutes: CIA Flying Suspects to Torture? (CBS television broadcast, Mar. 6, 2005).
} 
stated. ${ }^{388}$

The Bush administration disputes this. In March 2005, an anonymous U.S. official told the New York Times that "we check on those assurances, and we double-check on these assurances," that U.S. officials are assigned to verify that promises not to torture were kept, and that compliance was "very high". ${ }^{389}$ On February 16, 2005, CIA Director Porter Goss testified to the Senate Intelligence Committee that "of course, once [prisoners are] out of our control, there's only so much we can do. But we do have an accountability program for those situations." 390 Asked what Goss meant by an "accountability program," an anonymous intelligence official told the Washington Post that "in some cases, the U.S. government is allowed access and can verify treatment of detainees." 391

Scheuer doubted Goss' statement, arguing that " $[\mathrm{t}]$ hese are sovereign countries. They are not going to let you into their prisons." 392 Nabil Fahmy, Egypt's ambassador to the United States, denied his country's use of torture and stated that Egypt "wouldn't accept the premise that we would make a promise and violate it." Another Arab diplomat told the Post, "[i]t would be stupid to keep track of them because then you would know what's going on...It's really more like 'Don't ask, don't tell." One anonymous intelligence official told the Post that assurances were "a farce"; another, who had visited some of the prisons where suspects were sent, said that "[i]t's widely understood that interrogation practices that would be illegal in the U.S. are being used" and that "[t]hey say they are not abusing them, and that satisfies the legal requirement, but we all know they do." 393

There have been two reports of diplomatic consequences for countries that violated assurances not to torture prisoners. In December 2002, Dana Priest and Barton Gellman reported in the Washington

\footnotetext{
388 Id.

389 Douglas Jehl \& David Johnston, Rule Change Lets CIA Freely Send Suspects Abroad to Jails, N.Y. Times, Mar. 6, 2005 , at A1. 390 Id.

391 Dana Priest, CIA's Assurances on Transferred Suspects Doubted, WASH. Post, Mar. 17, 2005, at A1, available at http://www.washingtonpost.com/wp-dyn/articles/A42072 - 2005Mar16.html.. ${ }^{392} I d$.
} 
Post that "after years of fruitless talks in Egypt" about the treatment of suspects, "President Bill Clinton cut off funding and cooperation with the directorate of Egypt's general intelligence service." ${ }^{394}$ However, an anonymous Bush administration official told Priest and Gellman that in the wake of September 11, "[y]ou can be sure that we are not spending a lot of time on that now." 395 More recently, Newsweek reported that soon after Maher Arar was sent to Syria, "the administration made a secret decision to stop sending suspects to Syria. But officials acknowledge that such scruples are being ignored when it comes to rendering suspects to allies like Egypt and Jordan." 396 The official said the U.S. stopped sending prisoners to Syria because of concerns over suspects' treatment, ${ }^{397}$ but that may not have been the only factor; tensions with Syria over the situation in Iraq were mounting at approximately the same time. ${ }^{398}$

\section{ANALYSIS \& CONCLUSION}

.As a matter of U.S. law, Article 3 forbids deporting an alien if he can show "a chance greater than fifty percent that he will be tortured if removed." 399 Of the nineteen individual cases of rendition examined above, ${ }^{400}$ there have been specific allegations of torture in sixteen. In two cases, Talaat Fouad Qassem and Ahmad Mabrouk, the allegations of torture were not detailed and came from a source of suspect credibility, but cannot be entirely discounted because of Egypt's

\footnotetext{
393 Dana Priest, CIA 's Assurances on Transferred Suspects Doubted, WASH. Post, Mar. 17, 2005, at A1, available at http://www.washingtonpost.com/wp-dyn/articles/A42072 - 2005Mar16.html.

${ }^{394}$ Dana Priest \& Barton Gellman, U.S. Decries Abuse But Defends Interrogations, WASH. Post,

Dec.26, 2002, at A1, available at http://www.washingtonpost.com/ac2/wp-dyn/A37943 - 2002Dec25?language=printer.

395 Id.

396 Michael Hirsh, Mark Hosenball \& John Barry, Aboard Air CIA, NEWSWEEK, Feb. 28, 2005, at 32.

397 Id.

398 See, e.g., Seymour Hersh, The Syrian Bet, THE NEW YORKER, July 28, 2003, available at

http://www.newyorker.com/fact/content/?030728fa_fact ("Up through January of 2003, the coöperation was topnotch," a former State

Department official said. "Then we were going to do Iraq, and some people in the Administration got heavy- handed.").

399 Hamoui v. Ashcroft, 389 F.3d 821, 827 (9th Cir. 2004).

400 This does not include the two or three detainees alleged to have been rendered to Uzbekistan.
} 
extensive history of torturing similarly situated prisoners. In the other fifteen, the allegations of torture were much more detailed, and/or were consistent with other prisoners' or human rights reports' independent descriptions of torture in the same prisons, and/or were corroborated by press accounts, flight records, government documents, government officials, credible human rights organizations, or fellow prisoners. In the three cases where there have not been specific allegations of torture, Essam Hafez, Ihab Muhammad Saqr, and Jamil Qasim Saeed Muhammad, the prisoners have not been released or heard from since they were rendered to a country that routinely uses severe torture and is especially likely to use torture against suspected Islamic militants. This is also true of the prisoners allegedly rendered to Uzbekistan. There are zero cases where a prisoner has been released, or had contact with a family member, human rights worker, or other visitor, but has not made any allegations of torture. If these cases are at all representative, the odds of torture after a rendition seem closer to one hundred percent than fifty percent.

The administration would probably respond that these are individualized, fact-specific determinations and it is unfair to judge them in the aggregate. This was what Attorney General Gonzales argued during a Senate Judiciary Committee hearing on April 5, 2005, in response to three separate questions from Democratic Senator Patrick Leahy about the reliability of diplomatic assurances:

LEAHY: Do you think that the assurances we get from countries that are known to be torturers, when they say, "Well, we won't torture this person you're sending back" -- do you really think those assurances are credible? GONZALES: I think, Senator, that's a difficult question that requires, sort of, a case-by-case analysis....

LEAHY: Do you think that Uzbekistan's promise they will not torture detainees is trustworthy or even credible? GONZALES: I think a country that would have that kind of record, we would have to receive some very special assurances to satisfy ourselves in meeting our legal obligations....

LEAHY: I'm not sure that we really have standards. I mean, if our standards are to rely on their assurances they won't torture somebody, you really think, with some of the countries we send detainees to that, that's an adequate assurance?

GONZALES: Well, again, Senator, we take this obligation very, very seriously. And we know what are legal obligations are. We know what the directive of the president is. And each case is very fact-specific. ${ }^{401}$

${ }^{401}$ Hearing on the USA PATRIOT Act Before the Senate Comm. on the Judiciary, 109th Cong. (Apr. 5, 2005) (transcript on file with author). 
There are two problems with this defense. First, it contradicts almost every news report and CIA agent's description of the current procedure for obtaining and evaluating diplomatic assurances. ${ }^{402}$ According to the New York Times, shortly after September 11 the administration authorized the CIA to carry out renditions without an individualized review of each prisoner's case by the White House, Department of State, or the Department of Justice. ${ }^{403}$ According to the Washington Post, the CIA's legal staff "requires the station chief in a given country to obtain a verbal assurance from that country's security service. The assurance must be cabled back to CIA headquarters before a rendition takes place." ${ }^{404}$ Assurances are accepted even in cases when individual CIA agents have told reporters that "[y]ou would have to be deaf, dumb and blind to believe" them, ${ }^{405}$ and that "[t]hey say they are not abusing them, and that satisfies the legal requirement, but we all know they do." ${ }^{406}$ There are only two reports of the United States' deciding to stop accepting a country's assurances not to torture suspects, each described in only one news article. ${ }^{407}$ One of these decisions was apparently reversed after September 11, and the other may have had less to do with the country's violations of its promises not to torture than escalating tensions over other issues. ${ }^{408}$ If these reports are at all accurate, there is no "very fact-specific" "case-bycase" analysis of "very special assurances" before the prisoner is blindfolded and taken onto the jet.

Second, as discussed in Section II(A), to comply in good faith with Article 3 of the Convention Against Torture, before rendering a prisoner the government must consider "all

\footnotetext{
402 See Section III(C), supra.

403 Douglas Jehl \& David Johnston, Rule Change Lets CIA Freely Send Suspects Abroad to Jails, N.Y. TIMES, Mar. 6, 2005, at A1

404 Dana Priest, CIA's Assurances on Transferred Suspects Doubted, WASH. Post, Mar. 17, 2005, at A1, available at

http://www.washingtonpost.com/wp-dyn/articles/A42072 - 2005Mar16.html.

405 Shannon McCaffrey, Canadian Sent to Syrian Prison Disputes U.S. Claims Against Torture, KNIGHT-RIDDER, Aug. 1, 2004.

406 Dana Priest, CIA's Assurances on Transferred Suspects Doubted, WASH. PosT, Mar. 17, 2005 , at A1.

407 Dana Priest \& Barton Gellman, U.S. Decries Abuse But Defends Interrogations, WASH. Post, Dec. 26, 2002, at A1; Michael Hirsh, Mark Hosenball \& John Barry, Aboard Air CIA, NEwSWEEK, Feb. 28, 2005, at 32.

408 Dana Priest \& Barton Gellman, U.S. Decries Abuse But Defends Interrogations, WASH. Post, Dec. 26, 2002, at A1; Seymour Hersh, The Syrian Bet, THE NeW YORKER, July 28, 2003.
} 
evidence relevant to the possibility of future torture," including "[e]vidence of gross, flagrant or mass violations of human rights within the country of removal" and any "[o]ther relevant information regarding conditions in the country of removal." ${ }^{409}$ A country's record of torturing terrorism suspects the United States renders into its custody, in violation of its diplomatic assurances, is very strong "evidence relevant to the possibility" that the same country will torture the next prisoner that the United States renders into its custody in violation of its diplomatic assurances. If a "case-by-case analysis" means that evidence of torture of other prisoners rendered to the same country is disregarded, it violates Article 3.

However, given the emphasis that Article 3 places on a country's human rights record, it is reasonable to do a country-by-country analysis of the danger of torture after a rendition, instead of looking at all renditions to all countries in the aggregate.

In deciding whether country conditions compel the conclusion that an individual is more likely than not to be tortured if returned, Circuit Courts give a great deal to the applicant's membership in a group that the state has a history of torturing, and the likelihood that the applicant will be imprisoned upon his return. When a suspect is rendered to Egypt, Syria, or Uzbekistan, both these factors are present. The suspect is certain to be detained and interrogated in a country that routinely tortures prisoners, and the state has a history of murdering or torturing people in his exact situation.

In both Figueroa-Hincapie v. Fasano and Farah v. Ashcroft, the Ninth Circuit held that the torture or murder of two individuals who were similarly situated to the applicant compelled the conclusion that an applicant was more likely than not to be tortured. ${ }^{410}$ For a detainee about to be rendered to Egypt, there have been sixteen individuals who were almost identically situated to the prisoner: they were rendered by the United States into Egyptian custody for detention and interrogation, and Egypt promised the United States not to torture them. Fourteen of these sixteen have allegedly been tortured, and the two others have been held incommunicado and may have been tortured. In all but two cases the allegations of torture are

409 8 C.F.R. § 208.16(c)(3) (2004).

${ }^{410}$ Figueroa-Hincapie v. Fasano, 86 Fed. Appx. 283, 286 (9th Cir. 2004), Farah v. Ashcroft, 114 Fed. Appx. 325 (9th Cir. 2004). 
fairly detailed, and human rights groups have found them credible. Prisoners who were detained separately, and in some cases detained years apart, have made very similar accusations about their treatment. ${ }^{411}$ In two cases, it seems quite likely that the individual was returned to U.S. custody with severe injuries resulting from torture. In at least six other cases, government documents or government officials corroborate the torture allegations. Based on news reports and administration statements about the rendition policy, the United States probably obtained diplomatic assurances from Egypt not to torture the prisoner in every single one of these cases. These assurances do not seem to have reduced the risk of torture at all.

There are two confirmed cases where the United States sent a prisoner to be interrogated in Syria, and two other cases where a Canadian citizen traveled to Syria voluntarily and was arrested there, most likely at the United States' request. All four men were almost certainly tortured. Maher Arar has told the same detailed, consistent story since he returned to Canada, and almost all aspects of it have now been confirmed by independent sources. Both Arar and Muhammad Haydar Zammar seem to have been held in nearly identical underground, grave-like cells in the Palestine Branch, and American officials' statements demonstrate that they knew or strongly suspected that both Arar and Zammar were being tortured. Canadian government documents support Ahmad el-Maati's allegations of torture, and based on Arar's and his family members' reports Abdullah Almalki was beaten much more severely than the other two Canadians. The United States may not have obtained diplomatic assurances about Almalki's or el-Maati's treatment since they were detained overseas, but it very likely did in Zammar's case and certainly did in Arar's. Those assurances proved worthless.

None of the prisoners rendered to Uzbekistan has been identified by name or released, but the State

\footnotetext{
${ }^{411}$ For example, compare:

- Mamdouh Habib's description of water-filled rooms, supra Section III(B)(1)(a), to Shawki Attiya's and Essam Tawwab's references to them, supra Section III(A)(2).

- $\quad$ Ahmed Naggar's description of being given shocks from an electrified mattress and chair, supra Section III(A)(2), to Ahmed Agiza's similar descriptions, supra Section III(B)(1)(b).

- Ahmed Saleh's and Muhammad Tita's descriptions of being suspended from the ceiling of their cells and being given electric shocks, supra Section III(A)(2).

- Ahmed el-Maati's description of being tortured with an “electric prod," supra Section I, and Mamdouh Habib's description of being
} 
Department human rights reports demonstrate that torture is extremely common and extremely brutal in Uzbek prisons, and that those suspected of Islamic extremism are singled out for the harshest treatment. The State Department reports record six different instances of members of the Islamic organization Hizb ut-Tahrir being tortured to death in the past few years, and indicate that the real number may be significantly higher. There were many other cases of torture that was very severe but not fatal. There is no reason to believe that a prisoner rendered to Uzbekistan by the United States, accused not only of possessing banned pamphlets but of participation in violent Islamist terrorism, would be treated any less brutally. Obtaining assurances from Uzbekistan that it will not torture prisoners will do nothing to change this. If the Karimov regime's record of torture were not enough to undermine the value of its diplomatic assurances, its record of blatant falsification of medical reports would suffice. No rational person could rely in good faith on promises not to torture from the regime that attributed Emin Usman's and Shovruk Ruzimuradov's deaths to suicide, Ravshon Haitov's death to a heart attack, Mirzakomil Avazov's and Khusnuddin Olimov's deaths to a tea fight, and Orif Ershanov's death to high blood pressure.

The evidence, which Article 3 forbids the administration from ignoring, compels the conclusion that a suspect is more likely than not to be tortured after every rendition to Egypt, Syria, or Uzbekistan. No reasonable factfinder could determine that unverified promises not to torture, which those countries have violated in the past and which many CIA officers say are worthless, reduce the odds of torture to less than fifty percent.

In the case of rendition to Jordan and Morocco, there is not yet enough publicly available evidence to compel the conclusion that a suspect is more likely than not to be tortured after a rendition. There is only one publicly known case of rendition to each country. In Jordan the prisoner has not been released and there is some possibiblity that he is being held in CIA custody rather than being rendered; in Morocco the prisoner's allegations of torture have not been corroborated as

tortured with an "electric cattle prod," supra Section Section $\operatorname{III}(B)(1)(a)$. 
thoroughly as in some other cases. And while both countries' intelligence services torture prisoners, the State Department reports portray their use of torture as less pervasive and less brutal than Egypt's, Syria's, or Uzbekistan's.

But while the publicly available evidence does not compel the conclusion that every suspect rendered to Morocco or Jordan is more likely than not to be tortured, the administration has access to much more information than the public. If Benyam Muhammad's story is true, U.S. soldiers or intelligence personnel have seen and photographed the injury to his chest and genitals received in a Moroccan jail. The administration probably knows where Jamil Qasim Saeed Muhammad is being imprisoned, and may know whether he has been mistreated. It also knows which other prisoners have been rendered to Morocco and Jordan, and may know whether they have returned to U.S. custody with injuries or made credible allegations of torture.

Again, Article 3 of the CAT requires the administration to consider all this evidence before deciding to transfer a prisoner. Combined with the evidence that unverified diplomatic assurances from countries known to torture prisoners do almost nothing to reduce the risk of torture, it may very well demonstrate that any prisoner rendered to Morocco or Jordan for interrogation is more likely than not to be tortured. If so, transferring prisoners to those countries violates the Convention Against Torture and FARRA.

All of this is true whether or not Maher Arar's lawsuit is dismissed for lack of jurisdiction, lack of a cause of action, lack of standing, or to protect state secrets. It is true whether or not any judge ever rules that it is true. The U.S. Constitution states that "all Treaties made, or which shall be made, under the Authority of the United States, shall be the supreme Law of the Land." 412 It also states that the President "shall take care that the laws be faithfully executed." 413 The executive branch has an

412 U.S. CONST. art. VI, cl. 2

413 U.S. CONST. art. II, $\S 3$. 
obligation to obey the Convention Against Torture, FARRA, and the Anti-Torture Statute even if no court has the power to force the executive to obey or penalize it for disobedience. The limits that Congress places on the courts' authority to enforce Article 3 of the Convention Against Torture and FARRA do not limit the executive's obligation to comply with those laws in good faith. 